\title{
Quartz use in the absence of flint: Middle and Upper Palaeolithic raw material economy in the Côa Valley (North-eastern Portugal)
}

\author{
Thierry Aubry*, António Fernando Barbosa, Luís Luís, André Tomás Santos, \\ Marcelo Silvestre \\ Côa Parque, Fundação para a Salvaguarda e Valorização do Vale do Côa, Rua do Museu, 5150-610 Vila Nova de Foz Côa, Portugal
}

\section{A R T I C L E I N F O}

\section{Article history:}

Available online 15 December 2015

\section{Keywords:}

Côa Valley

Lithic raw material

Upper and Middle Palaeolithic

Quartz

Lithic Economy

\begin{abstract}
A B S T R A C T
Differing from most of European Upper Palaeolithic record, the Côa Valley lithic assemblages reveal an intensive use of a large variety of quartz and quartzite available locally. New surveys of the lower Côa Valley quartz veins were carried out in order to establish potential areas of raw material exploitation by hunter-gatherers through the identification of the raw material sources present in the archaeological record. Upper Palaeolithic lithic assemblages are produced on local quartz varieties, regional fine-grained quartz veins and flint and silcrete from long distance sources. The proportion of raw material and their choice for different tool types reveal some variation through the Upper Palaeolithic sequence, but present the same diversity and large geographical range of supply. Middle Palaeolithic assemblages from the same region are essentially based on local lithic material, showing a more restricted exploitation area and revealing different technology and procurement strategies, possibly evidence of changes in mobility and social networks.
\end{abstract}

๑) 2015 Elsevier Ltd and INQUA. All rights reserved.

\section{Introduction}

The discovery of the Côa Valley Upper Palaeolithic open-air prehistoric rock art, located in North-eastern Portugal, along the last $22 \mathrm{~km}$ of this left bank tributary of the Douro River (Zilhão, 1997b; Baptista, 1999, 2009) has radically changed our understanding of Late Pleistocene societies and peopling of Iberia. Subsequently, the discovery and study of an archaeological context for the rock art has enabled us to establish a significant occupation in this region of Iberia, during several periods of the Upper Palaeolithic (Zilhão, 1997b; Zilhão et al., 1995; Aubry, 2001, 2002, 2009), partially contradicting the accepted logistic hunting sites model for the Iberian hinterland's scarce occurrences (Davidson, 1986).

The study of lithic raw material used by Upper Palaeolithic foragers of the Côa Valley has revealed an intensive and predominant use of quartz, which is present through its different mineralogical forms in the hydrothermal veins of the site surroundings (Aubry, 2009; Aubry et al., 2012). Such a case is not uncommon in Portugal, where all lithic assemblages series show a systematic use of quartzite and quartz, and rare blade production, even at sites

\footnotetext{
* Corresponding author.

E-mail addresses: thaubry@sapo.pt, thierryaubry@arte-coa.pt (T. Aubry).
}

where flint sources exist in the vicinity (Zilhão, 1997a; Almeida, 2000; Bicho, 2000).

The Côa Valley is located in the Hercynian Massif, a long way from the nearest flint sources. In this area, quartz and Ordovician quartzite are available as pebbles and cobbles in secondary position in the Côa, Ribeira de Aguiar and Douro alluvial deposits. These local raw materials are archaeologically associated with small quantities of fine-grained hydrothermal siliceous rocks from regional outcrops and long distance flint and silcrete sources formed in a sedimentary environment, absent from the regional geological context (Mangado Llach, 2005). The interpretation of the discard of flints, coming from Central Portugal and Central Mountain System's northern and southern margins, and silcrete, from the northern and southern Meseta and the Lusitanian basin, has provided an unique opportunity to study the origin and to interpret the displacement of these materials, which show long distance connections with other areas of the Iberian Peninsula, namely Central Spain and Central Portugal, that hint at mobility patterns and long distance social relations (Aubry et al., 2014a).

The aim of this study is to define the origin of quartz materials and their use during the Upper Palaeolithic in comparison with Neanderthal and Holocene foragers of the same geographical area. In order to better understand local resources exploitation and their relation with regional and long distance raw materials, new field 
surveys were carried out to establish more precisely the regional resource availability and variability. To identify patterns in their choice and use through time, Upper Palaeolithic assemblages are compared to the Cardina I Middle Palaeolithic layer, recovered during the 2014 excavation campaign, and the Olga Grande 6 Mesolithic lithic assemblage.

\section{Material and methods}

The lower Côa River Valley and its confluence with the Douro River, corresponds to the Alto Douro region, geologically located in the northern sector of the Central Iberian Geotectonic Zone, part of the Iberian Hercynian Massif, consisting on the most continuous fragment of Variscan basement in Europe (Ribeiro, 1974, 1981; Ribeiro et al., 1979). The regional geology (Ribeiro, 1974; Silva et al., 1989; Ribeiro et al., 1990; Silva and Ribeiro, 1991; Pereira, 2001; Ribeiro, 2001; Pereira, 2006) comprises widespread outcrops of intensely folded and faulted metasedimentary rocks (schist, greywacke and quartzite), intruded by granite, ranging in age from Precambrian to Ordovician (Cabral, 1989; Silva and Ribeiro, 1991; Carvalho, 1992; Ribeiro, 2001). Both granitic and metasedimentary rocks are crossed by quartz, pegmatite, microgabbro/basalte, and rhyolite veins, following the main regional tectonic structures. Cenozoic and Quaternary sedimentary rocks (mainly sandstone and conglomerates) cover the Palaeozoic and Precambrian basement, as well as the Hercynian granitoids.

Since 1995, more than 15 Upper Palaeolithic archaeological sites have been identified in the Côa Valley (10 of which were tested or excavated) in an area of less than $400 \mathrm{~km}^{2}$, along the river's lower $9 \mathrm{~km}$, both on the valley bottom and on the granitic bedrock of the surrounding plateau (Zilhão et al., 1995; Aubry et al., 2002; Aubry and Sampaio, 2008; Aubry, 2009). A relative chronology of the different phases of the Côa Valley Upper Palaeolithic settlement was established from stratigraphic sequences identified at the sites where a geoarchaeolological approach was applied (Aubry et al., 2010). The knowledge of Middle Palaeolithic settlement in the area was initially based on surface survey findings, revealing Levallois technology, and the stratigraphical position of few lithic remains recovered in layer 4 , at the bottom of the Olga Grande 4 sequence. This settlement is now attested under Cardina's Middle Gravettian occupation level $4 \mathrm{~b}$ and Early Upper Palaeolithic remains recovered at the top of layer 5 (5.1 to 5.12) (Fig. 1).

Radiometric dates were obtained at four Côa Valley sites, by luminescence applied on burnt quartz and quartzite pebbles and by Optically Stimulated Luminescence on sediments at Cardina 1, Olga Grande 4, Quinta da Barca Sul and Fariseu (Valladas et al., 2001; Mercier et al., 2001, 2006, Fig. 1). The acid soils developed on schist and granite bedrock of the region do not favour the preservation of macro organic remains. However, bones and teeth were recovered in the stratigraphic level 4 of Fariseu (Aubry et al., 2007; Aubry and Sampaio, 2008; Aubry, 2009), where faunal remains are unusually preserved (Gabriel and Béarez, 2009), and in the Magdalenian and Gravettian occupation levels of Cardina I site. Upper Palaeolithic radiocarbon ages were obtained on bones from the layer 4 at Fariseu. The $\mathrm{N}$ content tested on Cardina I faunal remains has revealed that collagen is not sufficiently preserved in the remains analysed in order to obtain radiocarbon ages (Monge Soares, ITN, pers. comm.). Nevertheless, a charcoal fragment from Fariseu's layer 9 was dated by AMS to $19,020 \pm 80{ }^{14} \mathrm{C}$ BP (GrA$40167 ; 22,878 \pm 296$ calBP, using CalPal_2007_HULU [www.calpalonline.de]), which demonstrates the potential conservation of Last Glacial Maximum macro organic materials in alluvial deposits. The ages obtained at the four sites have confirmed the typological attribution of the stone tool assemblages found therein and attest human presence during several phases in the 31,000-12,000 interval (Aubry, 2009; Aubry et al., 2014b).

The method used to detect, characterize and study extra regional flint and silcrete, relying on field work and microscopic analysis on thin section of selected samples, in order to identify the sources of the lithic raw material found at Côa Valley Upper Palaeolithic sites, is discussed elsewhere (Aubry et al., 2012, 2014a). For the regional and local hydrothermal vein quartz varieties, the approach is based on systematic descriptions and comparisons of archaeological and geological samples following the genetic and gytological classification, which considers in situ outcrops (0), subprimary outcrops (1), colluvial gathering (2), recent river deposits (3) and old alluvial deposits (4), as proposed by Fernandes et al. (2008). We have included recent data resulting from new surveys of hydrothermal quartz vein from the Côa Valley, Massueime and Douro tributaries, which were carried out from December 2014 to March 2015. The field work was based on geological data provided by the Instituto Geológico e Mineiro de Portugal (Carta Geológica de Portugal, Scale 1:50,000) and the inventory of Portuguese mineral occurrences and resources (SIORMINP, <http://geoportal.lneg.pt/geoportal/egeo/bdssiorminp>). In this study, the definition of the quartz varieties and sources is based on a macroscopic approach, with no further data. Petrological and geochemical analyses of quartz materials are under development. In order to analyse the relation between typology, chronology and the raw material we have considered the retouched flakes, blades and bladelet types from the two excavation campaigns led in 2014 on the northern area of the Cardina site. For the same reason we have done a principal component analysis for the Côa Valley sites' blades and bladelets (typology from Zilhão, 1997a), using R Language (R Core Team, 2013) and its package FactoMineR (Husson et al., 2013). The respective factor maps were then reworked in Illustrator CS3 to enhance their legibility.

\section{Results}

\subsection{Quartz resources}

The lithic resource survey in the context of the PaleoCoa project has confirmed the existence of a large variety of quartz forms that composed the epithermal veins filling the Hercynian fracture network and has located the sources of most of the regional finegrained epithermal quartz vein sources that were systematically used during the Upper Palaeolithic in the region (Table 1, Figs. 2 and 3).

The most frequent form is milky quartz (J9), followed by grey (J12) and translucent anhedral quartz (J10) (Fig. 4). These are widely available as vein outcrops, highly fragmented by tectonics, or as fragments removed in slope or alluvial deposits, around all the archaeological sites studied (Figs. 2 and 3). Other quartz forms which have been observed are geographically more restricted. These very specific forms are closely related with successive deformation and filling phases (zoned translucent quartz - J11) or are found in direct association with uranium or gold mineralization (J1, J2, J5 and J8), confirmed by their mining exploitation (Cerveira, 1951 ). The cream to white microquartz and chalcedony variety (J7), and brown/yellow variety of microquartz and chalcedony (J1), called "jasper" in the mining literature, is noted in two distinct areas of the region surveyed (right bank of the Douro valley and Côa valley), as well as euhedral and anhedral smoky quartz (J8 and J17). These quartz forms, generally spatially associated, are related to the presence of uranium. Macroscopical binocular observations and comparison with archaeological remains of the Côa Valley assemblages indicate higher degree of similarity between J1 types used in the Côa valley archaeological sites and sources located along the 


\begin{tabular}{|lll|}
\hline & Colluvial deposit & $\mathrm{Cl}=$ Clay \\
& $\mathrm{Si}=$ Silt \\
Slope deposit & $\mathrm{f}=$ Fine Sand \\
$\mathrm{m}=$ Medium Sand
\end{tabular}

Quinta

da Barca Sul
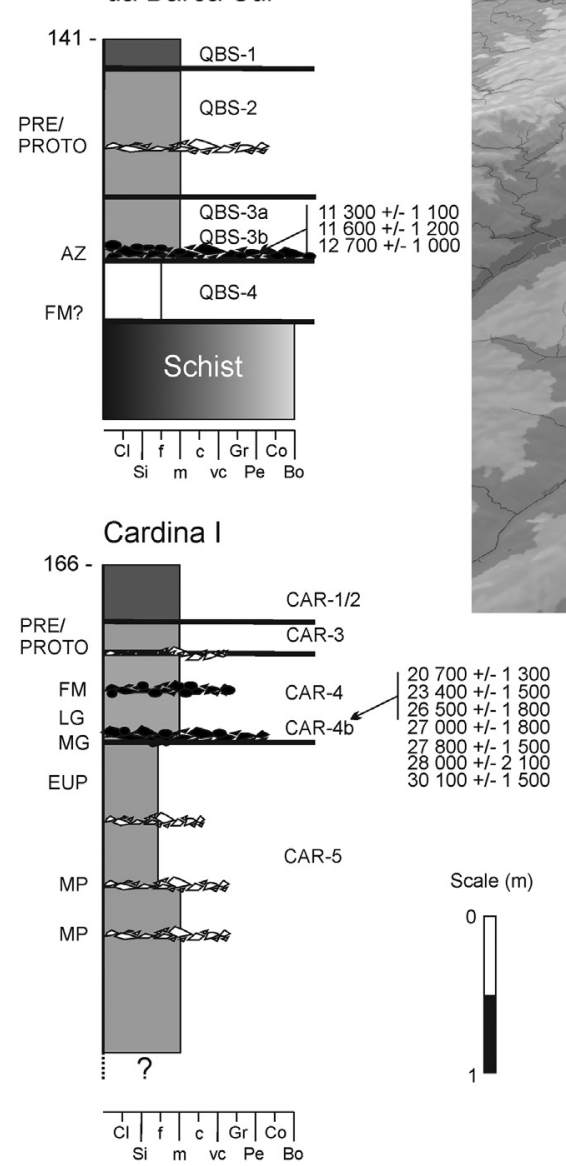

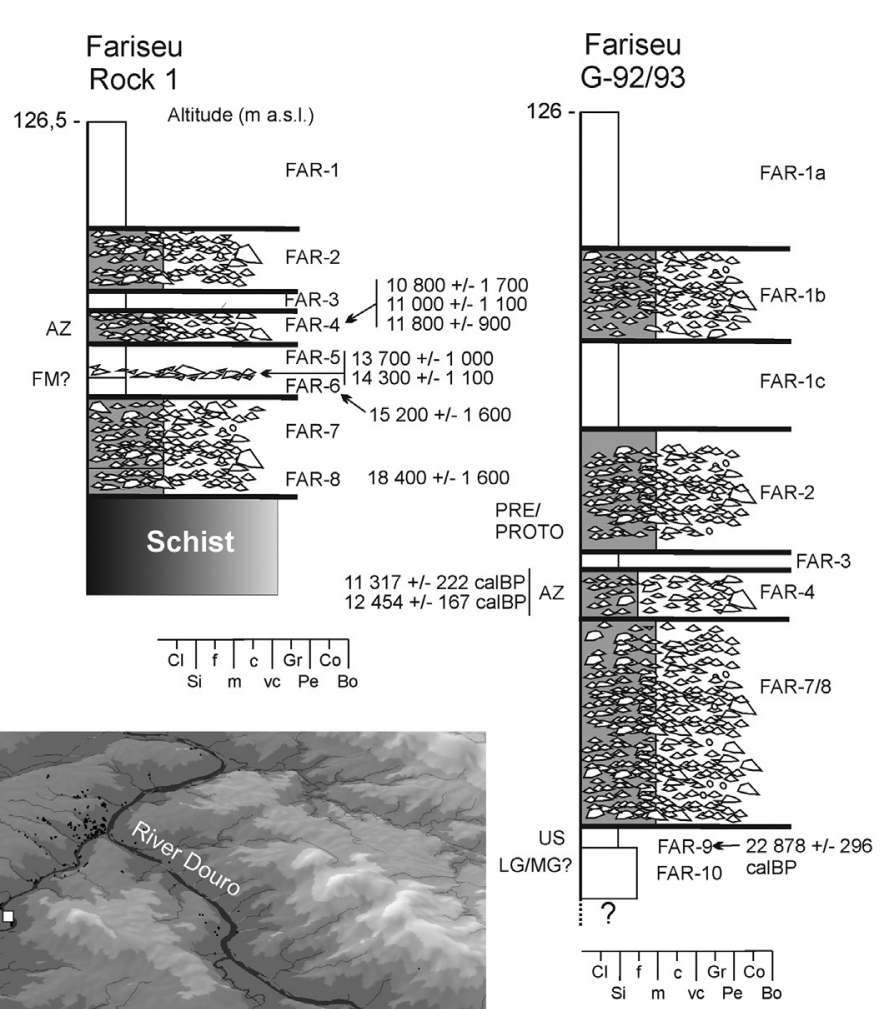

Insula II

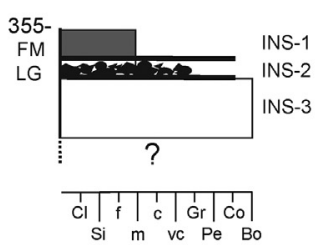

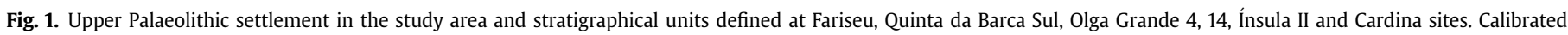

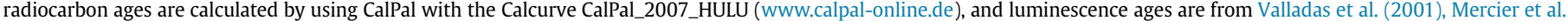
(2001, 2006) and Aubry (2009).

same river valley (Fig. 2). Geochemical analyses will be developed in order to test this hypothesis.

The green translucent microquartz and chalcedony (J2), attested in all the Upper Palaeolithic (Aubry, 2009) and Mesolithic (Monteiro-Rodrigues, 2011) sites, until now only attested by small veins fragments recovered in slope deposits (Aubry, 2009), has been observed in primary position and in considerable quantities, along a major fault (Fig. 2).

Euhedral milky quartz (J14) is frequently associated with anhedral milky quartz (J9), composing the largest quartz veins of the region with a NW-SE direction. Translucent to clear euhedral quartz (J13) has been also observed inside joint-fractures that have 


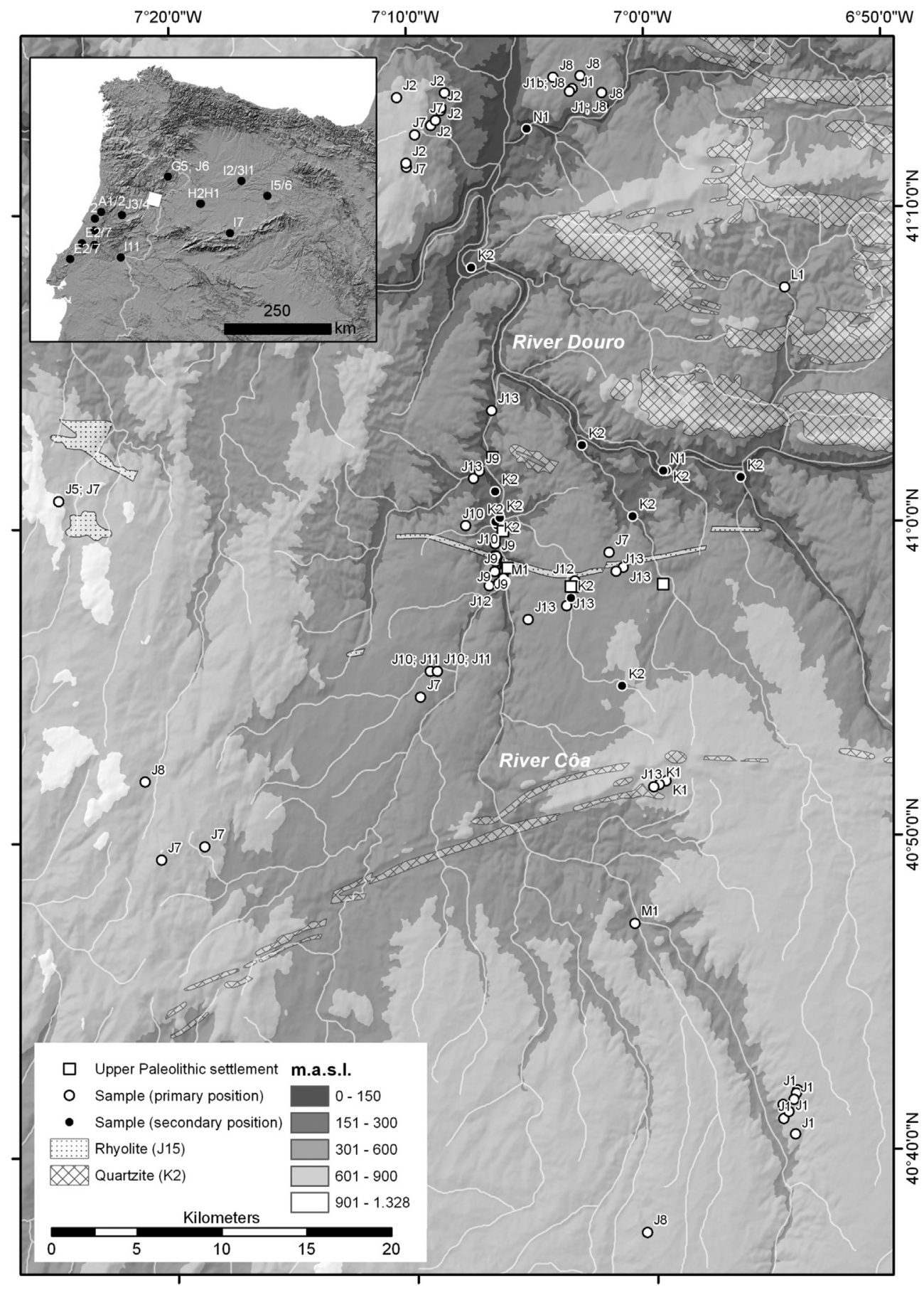

Fig. 2. Siliceous raw materials detected during the survey following the raw material codes defined in Table 1.

affected these main quartz veins and in other fractures in the lower Côa Valley metamorphic rocks. However, the equivalent in size and transparency of some of the euhedral quartz used during the Middle Gravettian of Olga Grande 4 layer 3 remains to be located.

\subsection{Differential use of quartz}

The Levallois and Discoidal lithic assemblage recovered in layer 5 of the Cardina sequence (551 pieces, Table 2, 5.13-32) is almost exclusively composed by anhedral translucent, milky or zoned quartz (Fig. 5). Few pieces (3) are made of rhyolite, available near the site as a large vein, and euhedral translucent quartz (10) (Fig. 3). The majority of the raw materials used in this layer could be found in the slope deposits surrounding the site and in the present-day alluvial deposits. The euhedral translucent to clear and milky quartz is found at less than $5 \mathrm{~km}$. Comparatively to the Upper Palaeolithic lithic assemblages recovered at the same site in the top of the layer $5(5.1-12)$, layer $4 \mathrm{~b}$ and 4 , it is noteworthy that quartzite is completely absent (Table 2). Only a flake and a blade were retouched as notches (Table 3 ). The survey of the present-day alluvial deposits near the site has not revealed quartzite cobbles similar to the archaeological blanks. Quartzite from the Ordovician 


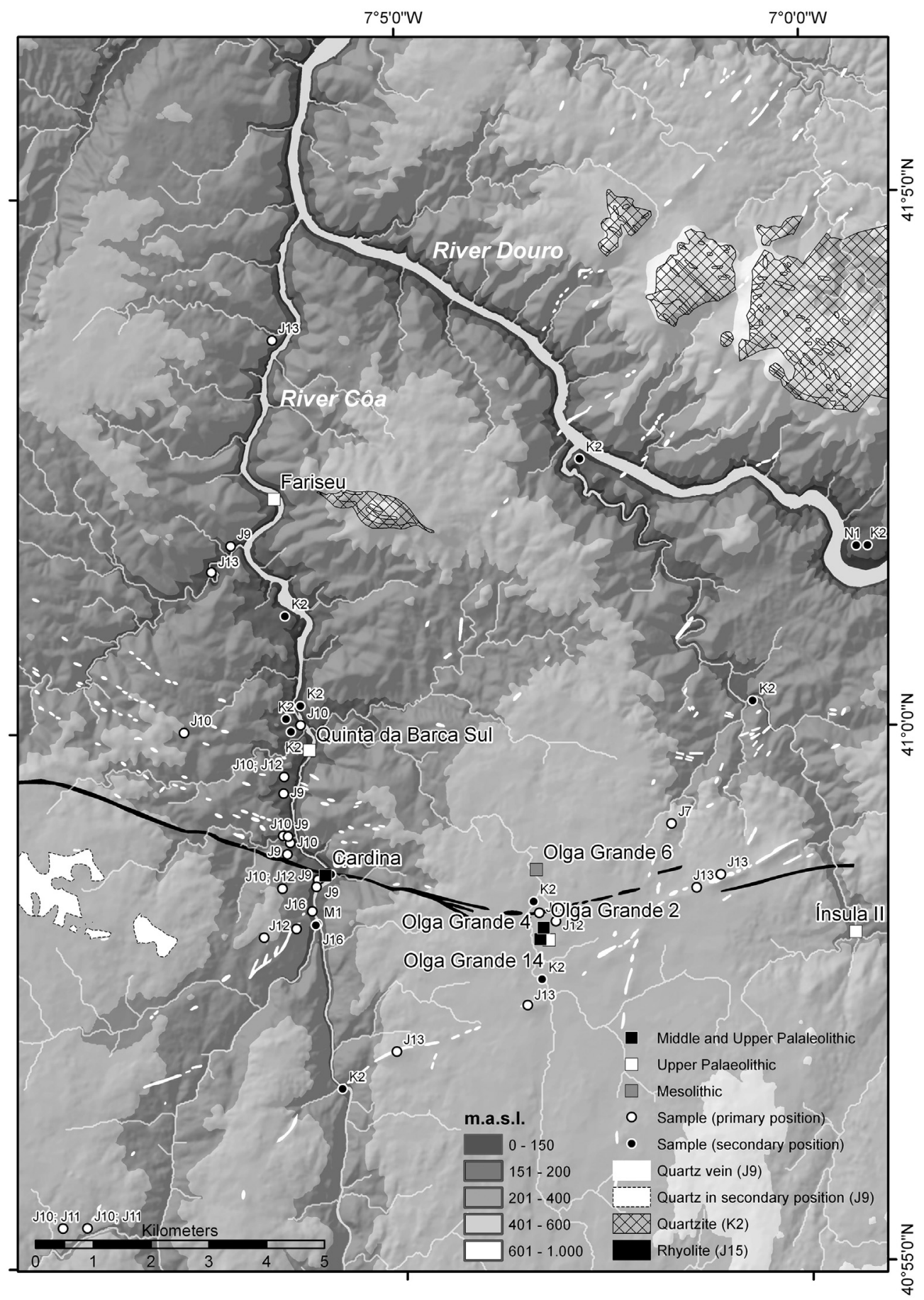

Fig. 3. Local lithic raw materials in the context of the Côa valley Upper and Middle Palaeolithic sites studied.

relief located $15 \mathrm{~km}$ upstream is attested as intensively rounded cobbles in Raña Pliocenic deposits, locally preserved on the Meseta surface (Fig. 2), in the Quinta da Barca Eemian terraces, and in the present-day alluvial deposit of the Penascosa/Quinta da Barca and Mouchão da Faia fluvial terraces, respectively located $3 \mathrm{~km}$ downstream and upstream (Fig. 3).

A quartzite Levallois flake was discovered in Olga Grande 4 layer 5 , associated with local anhedral grey quartz non-diagnostic pieces (Fig. 6, $\mathrm{n}^{\circ} 3$ and 4), underlying Middle Gravettian occupation level, intercalated by a sterile layer (Fig. 1). Quartzite is locally available in the Ribeirinha alluvial deposits. The flakes obtained by a Levallois technology discovered in layer 2 of Olga Grande 2, are made from rhyolite (Fig. $6, \mathrm{n}^{\circ} 1$ and 2 ) which is available in a thick vein a few metres from the site (Figs. 2 and 3 ).

The undetermined lithic assemblage from the Fariseu layer 10, the Middle Gravettian occupation of the bottom of the Côa valley (Cardina I, layer 4b), of the granitic plateau (Olga Grande 4 and 14, layer 3), and the Late Gravettian occupation attested at Cardina I (layer 4/10) and Ínsula II show the highest proportion of quartzite known for the Upper Palaeolithic sites of the region (Table 2). The Gravettian assemblages are also characterized by a direct 
Table 1

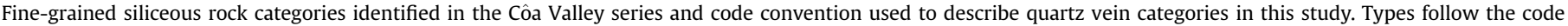

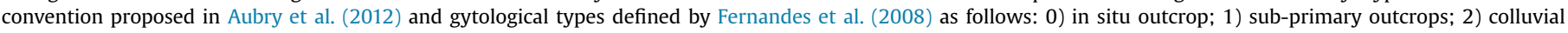
gathering; 3 ) recent river deposits; 4) old alluvial deposits.

\begin{tabular}{|c|c|c|c|}
\hline Genetic & Code & Gytology & Description \\
\hline \multirow[t]{8}{*}{ Flint } & A1 & $0 / 1 / 2$ & Hettangian/Sinemurian red marmorean flint with geode \\
\hline & $\mathrm{C} 1 / 2$ & $0 / 1 / 2 / 4$ & Bajocian/Bathonian grey to brown zoned flint (type 1) \\
\hline & $\mathrm{C} 3 / 4$ & $0 / 1 / 2 / 4$ & Bajocian/Bathonian grey to brown zoned flint (type 2) \\
\hline & $\mathrm{D} 1 / 2$ & $0 / 1 / 2$ & Oxfordian black/grey marmorean flint \\
\hline & $\mathrm{E} 2 / 7$ & $0 / 1 / 2 / 4$ & Cenomanian brown/red flint \\
\hline & I1 & $0 / 1 / 2 / 4$ & Indiferentiated Miocene flint \\
\hline & $\mathrm{I} 2 / 3$ & $0 / 1 / 2 / 4$ & Miocene Mucientes black/grey flint \\
\hline & $\mathrm{I} 11$ & 4 & Miocene flint in old alluvial terraces \\
\hline \multirow[t]{4}{*}{ Silcrete } & I7 & $0 / 1 / 2 / 4$ & Oligocene/Miocene translucent silcrete with black inclusions \\
\hline & G5 & $0 / 1$ & Oligocene/Miocene green to grey opal with detrital quartz \\
\hline & $\mathrm{H} 1$ & $0 / 1 / 2$ & Paleocene orange/yellow to cream opal with detrital quartz \\
\hline & $\mathrm{H} 2$ & $0 / 1 / 2$ & Paleocene grey/yellow to orange sandstone with opal matrix \\
\hline \multirow{17}{*}{ Hydrothermal veins } & $\mathrm{J} 1$ & $0 / 1$ & Brown/yellow microquartz/chalcedony \\
\hline & $\mathrm{J} 2$ & $0 / 1$ & Grey/Green translucent microquartz/chalcedony \\
\hline & $\mathrm{J} 3$ & $0 / 1$ & Red microquartz and chalcedony \\
\hline & $\mathrm{J} 4$ & $2 / 3 / 4$ & Red microquartz and chalcedony in secondary position \\
\hline & J5 & $0 / 1$ & Yellow to orange opal \\
\hline & J6 & $0 / 1$ & Peridotite red and translucent opal and chalcedony \\
\hline & $\mathrm{J} 7$ & $0 / 1$ & White/cream/grey microquartz/chalcedony \\
\hline & $\mathrm{J} 8$ & $0 / 1 / 2 / 3 / 4$ & Euhedral smoky and morion quartz \\
\hline & $\mathrm{J} 9$ & $0 / 1 / 2 / 3 / 4$ & Anhedral milky and grey quartz \\
\hline & $\mathrm{J} 10$ & $0 / 1 / 2 / 3 / 4$ & Anhedral translucent to clear quartz \\
\hline & $\mathrm{J} 11$ & $0 / 1 / 2 / 3 / 4$ & Anhedral zoned translucent to clear quartz \\
\hline & $\mathrm{J} 12$ & $0 / 1 / 2 / 3 / 4$ & Anhedral grey zoned quartz \\
\hline & $\mathrm{J} 13$ & $0 / 1 / 2 / 3 / 4$ & Euhedral translucent to clear quartz \\
\hline & $\mathrm{J} 14$ & $0 / 1 / 2 / 3 / 4$ & Euhedral milky quartz \\
\hline & $\mathrm{J} 15$ & $0 / 1 / 2 / 3 / 4$ & Rhyolite \\
\hline & $\mathrm{J} 16$ & $0 / 1 / 2 / 3 / 4$ & Micro-gabbro and basalte \\
\hline & $\mathrm{J} 17$ & $0 / 1$ & Anhedral smoky quartz \\
\hline \multirow[t]{5}{*}{ Metasediment } & K1 & $0 / 1 / 2$ & Ordovician brown iron siltstone \\
\hline & $\mathrm{K} 2$ & $0 / 1 / 2 / 3 / 4$ & Ordovician quartzite \\
\hline & L1 & $0 / 1$ & Silurian grey zoned chert \\
\hline & M1 & $0 / 1 / 2 / 3 / 4$ & Cambrian black fine hornfels \\
\hline & N1 & $0 / 1 / 2 / 3 / 4$ & Silurian lydite/Phtanite \\
\hline
\end{tabular}

relationship between the milky and translucent anhedral quartz to produce large endscrapers (Cardina I and Olga Grande 14), and by retouched flakes on quartzite flakes (Cardina I) or slabs (Olga Grande 4 and 14) transformed into inverse denticulate and large scrapers (Aubry, 2009). Olga Grande 4's layer 3 and Cardina I's 4b retouched bladelets were produced on extra-regional flint and silcrete, microquartz vein (J1, J2), fine-grained black hornfels (M1), iron siltstone (K1) and euhedral translucent to clear quartz (J13) (Aubry, 2009; Klaric, 2009; Klaric et al., 2009). Prismatic, unipolar and bipolar, truncated burin cores and anvil bipolar percussion reduction sequences were applied to euhedral translucent to clear quartz to produce bladelets (Fig. 7), using the same reduction sequence as used for flint, silcrete and the fine-grained quartz varieties (Aubry, 2009; Klaric, 2009).

During the Late Gravettian (Cardina 4/10 and Ínsula II), anhedral quartz economy and tool types reveal strong similarities with the Middle Gravettian assemblage, but the economy of euhedral translucent to clear quartz is quite distinct. Bladelets from this material are only transformed by marginal retouch and the diagnostic backed, truncated or bitruncated bladelets are made from black hornfels (M1), brown/yellow microquartz (J1), and long distance flint and silcrete sources (Aubry, 2009).

The Proto-Solutrean phase, characterized in Portugal by an intensive use of quartz (Table 2) for the production of bladelets from carinated or thick muzzled endscraper cores in the sites located nearby flint sources of Central Portugal (Zilhão, 1997a; Almeida, 2000) is attested in layer 2c of Olga Grande 14 (Fig. 1). Large flakes removed from discoidal cores and used as blanks for thick muzzled endscraper core for bladelet production, are made from the local anhedral quartz. This lithic assemblage presents the highest proportion of quartz and the lowest of quartzite of all the Upper Palaeolithic units, even though both are locally available (Table 2).

Of the 24 Solutrean shouldered points recovered from Olga Grande 4 and 14, 20 are made from Central Portugal and Meseta flint and only 2 from the brown/yellow microquartz (J1) we attribute to the Côa Valley sources (Fig. 2). The formation process of the bottom of layer 2 of these sites, bearing the Solutrean diagnostically lithic artefacts, is complex, and these remains are mixed with others ascribed to the Magdalenian occupation of the site. Therefore taphonomy does not indicate if some of the non-diagnostic quartz and quartzite tools of layer 2 of the two sequences are contemporary with the Solutrean points.

The final Magdalenian lithic assemblage from Cardina I (layer 4.2 to 4.4 ) site reveals some differences with the Middle and Late Gravettian assemblages (Tables 2 and 3, Fig. 8). Quartzite proportion decreases and milky anhedral quartz is dominant. A large variety of exotic flint (from Central Portugal and Central Iberia) and regional microquartz and chalcedony veins (J1, J2, J7 and M1) are used for the production of the blanks of the backed bladelets. However, in contrast to the Middle Gravettian industry, where all the fine-grained raw materials are used to produce the same bladelet tool types, during the Final Magdalenian, as during the Late Gravettian, euhedral translucent to clear quartz is only used to produce small marginal retouched bladelet blanks.

Assemblages of Fariseu's layer 4 and Quinta da Barca's layer 3, both slightly younger than Cardina I Final Magdalenian occupation, confirm the trend observed in this last assemblage. In both those 


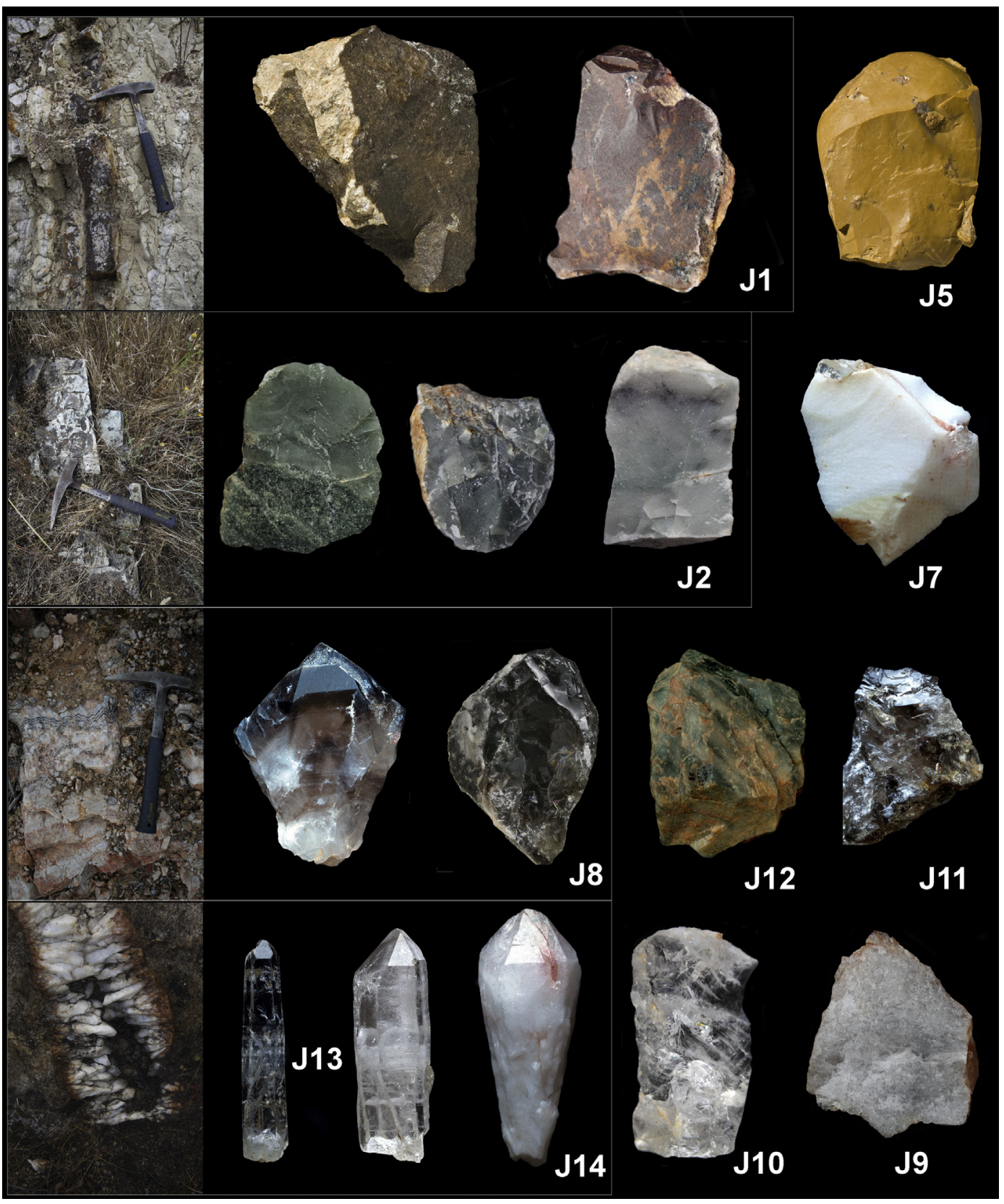

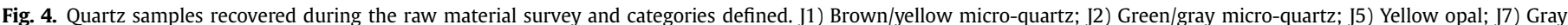

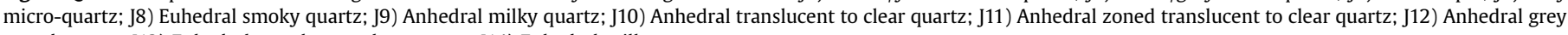
zoned quartz; J13) Euhedral translucent-clear quartz; J14) Euhedral milky quartz.

occupations, located nearby the bottom of the Côa Valley, anhedral quartz veins, milky and translucent to clear quartz are intensively used (Table 2). In Fariseu layer 4, most of these materials are not retouched. A very small proportion is transformed into notches, denticulates, scrapers and endscrapers (Tables 2 and 4). The Azilian points are made from long distance flint sources, brown/yellow (J1), green translucent quartz (J2) and black hornfels (M1), the last probably recovered in the Côa Valley alluvial deposits. At Quinta da Barca Sul, the sources used for the Azilian points are also used for the small circular endscrapers, profiting from the subproducts of the preparation of bladelet cores. Euhedral translucent to clear quartz is not used for the Azilian points, but, as in the Final Magdalenian, to produce marginal bladelet blanks, using soft hammer percussion or anvil bipolar percussion, as on other finegrained raw materials (Gameiro, 2009).

\section{Discussion}

The technologically Middle Palaeolithic lithic assemblage from the Cardina I, recovered in the 2 square metres excavated, indicates a selection of the raw materials presenting the finest textures among the local anhedral milky, translucent and zoned quartz varieties to produce flakes using Discoidal and Levallois reduction sequences (Fig. 5). The Olga Grande 4 layer 5 and Olga Grande 2 layer 2 data also indicates the choice of the local raw materials available (namely rhyolite, quartzite and anhedral grey quartz). It 


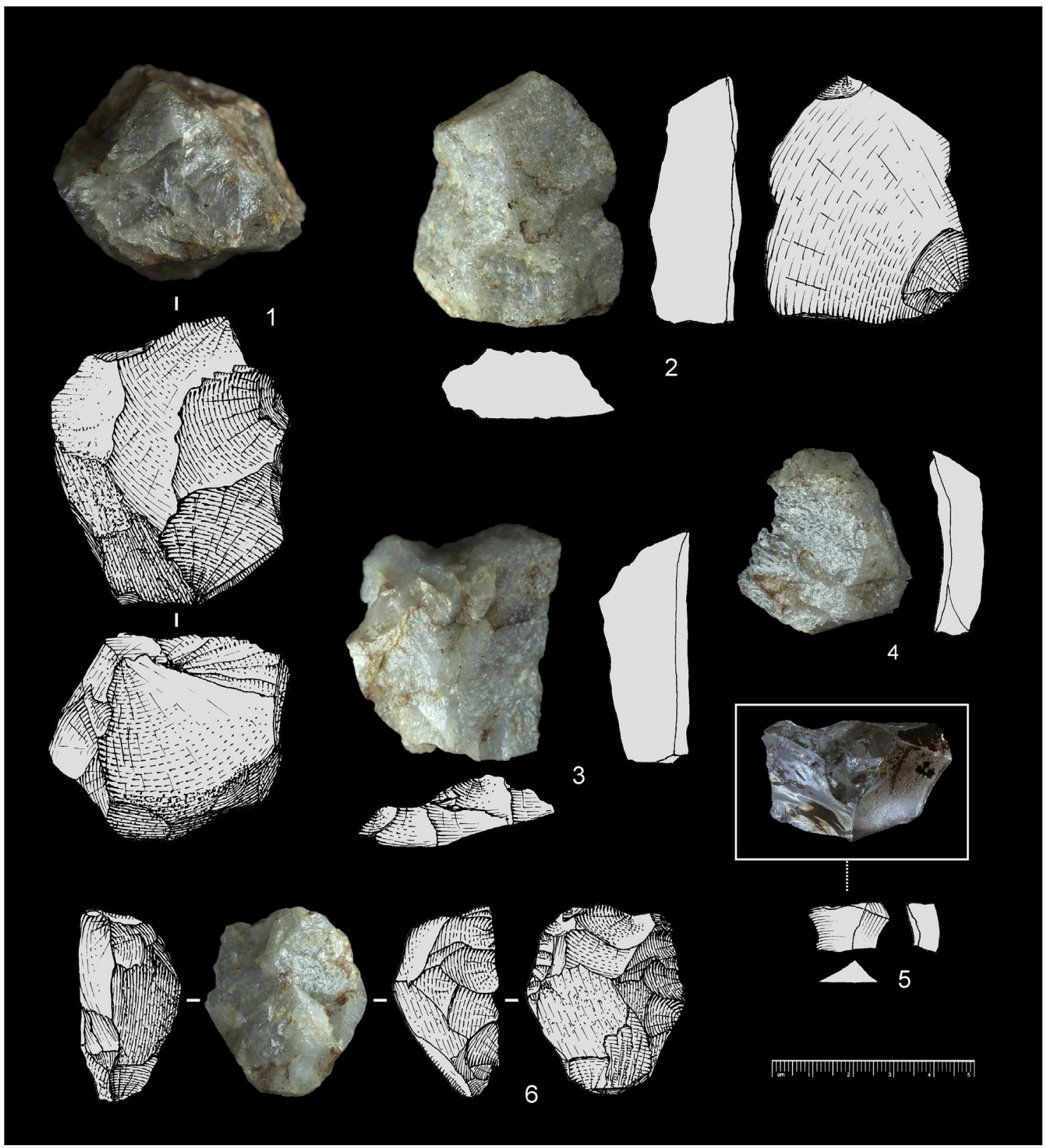

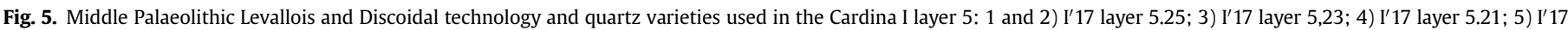
layer 5.18; 6) I'17 layer 5.26.

can be argued that the Middle Palaeolithic data of Cardina I is not sufficiently representative to infer behavioural patterns. However, when compared with the superposed Early Upper Palaeolithic layers (5.1-12), excavated in the same area, where regional and extra-regional microquartz and flint where found and quartzite is systematically present, it reveals a clear difference. If the use of quartz vein blanks locally available at Cardina can be perceived as a technological constraint, the absence of quartzite must be explained by the reduced lithic exploitation territory of the site. Quartzite is available less than $3 \mathrm{~km}$ upstream and downstream and was used in Olga Grande 4, where it is available at less than $200 \mathrm{~m}$ (Fig. 3).

Besides stratigraphy and technology, no other chronological data is currently available to date Cardina's Middle Palaeolithic and
Early Upper Palaeolithic occupation. From these early stages of Upper Palaeolithic, all the local, regional and extra-regional raw materials are present in Cardina I assemblages (Fig. 8 and Table 3). Even though the different raw materials vary in proportion, quartzite (metasediment in Fig. 8) and anhedral quartz are largely dominant in the production of tools from flakes. This situation differs from the blade and bladelet tool production, where flint, silcrete, euhedral quartz and microquartz vein are dominant.

In terms of morphometrics and considering length/width ratio of all the bladelet tools from the Côa valley sites, regardless chronology and typology, different raw materials present slightly different trends (Fig. 9). Euhedral quartz and flint and silcrete correspond to the thinnest bladelets, along with anhedral quartz, which was unexpected. Metasediment (exclusively hornfels), 
Table 2

Raw material categories effectives as defined in Table 1 used in the Côa Valley assemblages located in Fig. 1. Middle Palaeolithic (MP), Early Upper Palaeolithic (EUP), Middle Gravettian (MG), Late Gravettian (LG), Proto-Solutrean (PS), Final Magdalenian (FM), Azilian (AZ), Mesolithic (M) and Undetermined Upper Palaeolithic (?).

\begin{tabular}{|c|c|c|c|c|c|c|c|c|c|c|c|c|c|c|c|c|c|c|c|c|}
\hline & \multirow{2}{*}{$\begin{array}{l}\text { Site } \\
\text { Layer }\end{array}$} & \multirow{2}{*}{$\begin{array}{l}\text { Olga Grande } 4 \\
3\end{array}$} & \multicolumn{2}{|c|}{ Olga Grande 14} & \multicolumn{11}{|c|}{ Cardina } & \multirow{2}{*}{$\frac{\text { Ínsula II }}{2}$} & \multirow{2}{*}{$\begin{array}{l}\text { Quinta da } \\
\text { Barca Sul } \\
3\end{array}$} & \multicolumn{2}{|c|}{ Fariseu } & \multirow{2}{*}{$\begin{array}{l}\begin{array}{l}\text { Olga } \\
\text { Grande } 6\end{array} \\
2\end{array}$} \\
\hline & & & $2 c$ & 3 & 4.1 & 4.2 & 4.3 & 4.4 & 4.5 & 4.6 & 4.10 & $4 B$ & $4 B$ & $5.1-12$ & $5.13-32$ & & & 4 & 9,10 & \\
\hline & Cultural attribution & MG & PS & MG & $\mathrm{AZ}$ & FM & FM & FM & $?$ & $?$ & LG & $\overline{M G}$ & MG & EUP & MP & LG & $\mathrm{AZ}$ & $\mathrm{AZ}$ & $?$ & $\mathrm{M}$ \\
\hline & sq.m excavated & $\overline{75}$ & $\overline{12}$ & 12 & $\overline{18}$ & & & & & 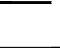 & $\overline{12}$ & $\overline{4}$ & $\overline{12}$ & 2 & 2 & $\overline{11}$ & 28 & 36 & 1 & 10 \\
\hline \multirow[t]{11}{*}{ Flint } & A1 & - & 2 & - & - & - & - & - & - & - & 8 & - & 2 & - & - & - & 1 & - & - & - \\
\hline & $\mathrm{C} 1 / 2$ & 8 & 6 & 2 & - & - & 5 & 4 & 3 & 1 & 45 & 3 & 24 & 1 & - & 4 & 2 & - & 5 & 2 \\
\hline & С $3 / 4$ & & & & - & - & - & - & - & - & & - & & - & - & & & & & \\
\hline & $\mathrm{D} 1 / 2$ & 31 & 17 & - & - & 4 & 4 & 6 & 1 & 1 & 16 & - & 9 & - & - & - & - & 3 & - & - \\
\hline & $\mathrm{E} 2 / 7$ & 14 & 8 & 5 & 7 & 10 & 21 & 6 & 17 & 6 & 96 & 19 & 81 & 7 & - & 11 & 3 & 19 & - & - \\
\hline & I1 & 144 & 16 & 16 & 6 & 32 & 40 & 34 & 14 & 7 & 402 & 39 & 331 & 15 & - & 15 & 6 & 10 & 2 & 2 \\
\hline & $\mathrm{I} 2 / 3$ & - & 4 & 5 & 3 & 5 & 3 & 2 & 3 & - & 134 & 5 & 85 & 3 & - & 2 & 7 & - & - & 1 \\
\hline & $15 / 6$ & - & - & - & - & - & - & - & - & - & 32 & - & 9 & - & - & - & - & - & - & - \\
\hline & I11 & - & 1 & - & 1 & - & - & - & - & - & - & 2 & - & - & - & - & 2 & 4 & - & - \\
\hline & Not determined & - & 2 & - & 5 & 13 & 10 & 6 & 5 & 1 & 96 & 7 & 62 & 4 & - & - & - & - & - & - \\
\hline & Burnt & - & 2 & - & 9 & 4 & 11 & 7 & 2 & - & 20 & 3 & 81 & 2 & - & 2 & - & 7 & - & - \\
\hline \multirow[t]{3}{*}{ Silcrete } & 17 & 7 & 3 & 4 & 2 & 1 & 8 & 3 & 2 & 1 & 49 & 2 & 30 & 1 & - & 9 & 2 & - & - & - \\
\hline & $\mathrm{H} 1$ & 2 & - & - & 1 & 1 & - & 1 & - & - & 1 & - & - & 3 & - & - & - & - & - & - \\
\hline & $\mathrm{H} 2$ & 6 & 2 & - & 1 & 2 & - & - & 1 & - & 22 & 1 & 10 & 1 & - & - & - & - & 2 & - \\
\hline \multirow{12}{*}{ Hydrothermal veins } & $\mathrm{J} 1$ & 21 & - & 8 & 2 & 3 & 12 & 14 & 7 & 5 & 11 & 10 & 12 & 11 & - & - & 32 & - & - & - \\
\hline & $\mathrm{J} 2$ & 3 & - & - & 1 & - & - & 1 & 2 & - & 5 & 1 & - & - & - & 1 & 22 & 26 & - & - \\
\hline & $\mathrm{J} 3 / 4$ & - & - & - & - & - & 1 & - & - & - & 11 & - & 9 & - & - & 1 & - & 15 & - & - \\
\hline & $\mathrm{J} 5$ & - & - & - & - & - & - & 1 & - & - & - & - & - & - & - & - & - & - & - & - \\
\hline & $\mathrm{J} 7$ & - & - & - & 4 & 2 & 2 & - & 1 & - & - & 2 & - & 1 & - & - & - & - & - & 1 \\
\hline & J9 & 7557 & 1316 & 25 & 1336 & 1751 & 1979 & 1617 & 765 & 306 & 9817 & 966 & 5967 & 616 & 465 & 836 & 774 & 3882 & 195 & 361 \\
\hline & $\mathrm{J} 10$ & & & & 333 & 441 & 664 & 552 & 260 & 129 & & 283 & & 170 & 35 & & & 1082 & & \\
\hline & $\mathrm{J} 11$ & & & & 33 & 28 & 32 & 47 & 15 & 4 & & 28 & & 34 & 38 & & & & & \\
\hline & $\mathrm{J} 12$ & & & & 7 & 4 & 7 & 8 & 2 & 1 & & 3 & & 1 & - & & & 20 & & \\
\hline & $\mathrm{J} 8$ & 968 & 92 & 108 & - & - & 2 & 2 & 41 & - & 5564 & 1 & 3411 & 1 & - & 142 & 16 & 237 & - & 170 \\
\hline & $\mathrm{J} 13$ & & & & 56 & 87 & 102 & 121 & 61 & 20 & & 90 & & 38 & 10 & & & & & \\
\hline & $\mathrm{J} 14$ & & & & 5 & 17 & 9 & 8 & - & 2 & & 5 & & 1 & - & & & & & \\
\hline Siltstone & K1 & 26 & 16 & 5 & - & 1 & 5 & 6 & 4 & - & 7 & 6 & 3 & 1 & - & 2 & - & - & - & - \\
\hline Quartzite & K2 & 971 & 71 & 174 & 284 & 511 & 472 & 469 & 187 & 64 & 11,875 & 357 & 8251 & 73 & - & 242 & 118 & 830 & 156 & 384 \\
\hline Hornfels & M1 & 1 & 25 & 3 & 4 & 17 & 29 & 20 & 5 & 2 & 2 & - & 6 & 7 & - & 1 & 8 & 2 & - & 3 \\
\hline Rhyolite & $\mathrm{J} 15$ & 19 & 19 & 1 & 29 & 40 & 76 & 75 & 40 & 11 & ? & 28 & ? & 9 & 3 & - & 3 & 4 & - & 10 \\
\hline Micro-gabbro & $\mathrm{J} 16$ & - & - & - & 14 & 17 & 16 & 23 & 10 & 2 & - & 15 & - & 3 & - & - & - & 1 & - & 4 \\
\hline Lydite & N1 & - & - & - & - & - & - & - & - & 1 & - & - & - & - & - & - & - & - & - & - \\
\hline
\end{tabular}


Table 3

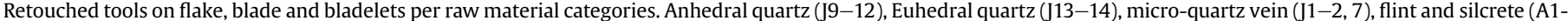

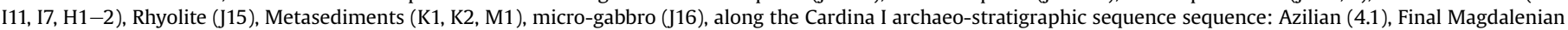
(4.2 to 4.5), Magdalenian to Gravettian (4.6 to 4.8), Middle Gravettian (4b), Early Upper Palaeolithic (EUP), Middle Palaeolithic (MP).

\begin{tabular}{|c|c|c|c|c|c|c|c|c|c|c|c|c|c|c|c|}
\hline \multirow[t]{2}{*}{ Layers } & \multicolumn{7}{|l|}{ Flakes } & \multicolumn{7}{|c|}{ Blades \& bladelets } & \multirow[t]{2}{*}{ Total } \\
\hline & $\begin{array}{l}\text { Anhedral } \\
\text { quartz }\end{array}$ & $\begin{array}{l}\text { Euhedral } \\
\text { quartz }\end{array}$ & $\begin{array}{l}\text { Micro- } \\
\text { quartz vein }\end{array}$ & $\begin{array}{l}\text { Flint \& } \\
\text { silcrete }\end{array}$ & Rhyolite & $\begin{array}{l}\text { Meta- } \\
\text { sediment }\end{array}$ & $\begin{array}{l}\text { Micro- } \\
\text { gabbro }\end{array}$ & $\begin{array}{l}\text { Anhedral } \\
\text { quartz }\end{array}$ & $\begin{array}{l}\text { Euhedral } \\
\text { quartz }\end{array}$ & $\begin{array}{l}\text { Micro-quartz } \\
\text { vein }\end{array}$ & Flint \& silcrete & Rhyolite & $\begin{array}{l}\text { Meta- } \\
\text { sediment }\end{array}$ & $\begin{array}{l}\text { Micro- } \\
\text { gabbro }\end{array}$ & \\
\hline Recent & 1 & - & - & - & - & - & - & - & - & - & - & - & - & - & 1 \\
\hline Neolithic & 17 & 1 & - & 3 & - & 6 & 1 & 4 & 3 & 1 & 7 & 1 & 1 & - & 45 \\
\hline $4 / 1$ & 4 & - & - & 3 & - & 1 & - & 2 & 4 & 3 & 2 & - & - & - & 19 \\
\hline $4 / 2$ & 12 & 2 & - & 3 & - & 4 & - & 3 & 7 & - & 6 & - & 2 & - & 39 \\
\hline $4 / 3$ & 15 & - & 1 & 3 & 1 & 4 & - & - & 5 & - & 8 & - & - & - & 37 \\
\hline $4 / 4$ & 18 & 3 & 1 & - & - & 4 & - & 6 & 6 & 2 & 7 & 1 & 4 & - & 52 \\
\hline $4 / 5$ & 11 & 1 & 1 & 1 & - & 39 & - & 1 & 1 & 1 & 7 & - & - & - & 63 \\
\hline $4 / 6$ & 8 & 2 & 1 & 3 & 1 & - & - & 2 & 2 & 1 & 3 & - & - & - & 23 \\
\hline $4 / 7$ & 7 & - & - & 1 & - & 3 & - & 1 & - & 1 & 1 & - & - & - & 14 \\
\hline $4 / 8$ & 4 & - & - & 1 & - & 4 & - & 1 & 1 & 1 & 8 & - & - & - & 20 \\
\hline $4 b$ & 2 & 1 & - & 2 & - & 3 & 1 & - & 5 & 1 & 3 & - & 1 & 1 & 20 \\
\hline EUP & 11 & 1 & - & 3 & - & 2 & - & 2 & 5 & 2 & 6 & - & - & - & 32 \\
\hline $\mathrm{MP}$ & 1 & - & - & - & - & - & - & 1 & - & - & - & - & - & - & 2 \\
\hline Total & 111 & 11 & 4 & 23 & 2 & 70 & 2 & 23 & 39 & 13 & 58 & 2 & 8 & 1 & 367 \\
\hline
\end{tabular}

rhyolite and, to a lesser degree, microquartz vein show thicker bladelets. The different raw material textures, which is petrologically determined, is dominant, regardless of technology and use.

Data available for Cardina I (layer 4b and 4/10) and Olga Grande 4 (layer 3 ) indicate that flakes from local quartz and quartzite were seldom retouched (Aubry and Araújo Igreja, 2009). Use-wear marks on retouched and unretouched blanks are underdeveloped, revealing that tools on flakes were not intensively used. The opposite happened with retouched bladelets, shown by the frequency of fractures which morphology diagnoses as projectile impact (Aubry and Araújo Igreja, 2009). The numerical importance of flake production on quartz and quartzite, along with the usewear data suggests an immediate use and discard of the raw or retouched edges.

To go beyond the raw material limitations we have carried a principal component analysis on the bladelets of the several excavated contexts of the region considering four main types of retouched bladelets (backed bladelets, backed points, marginally retouched bladelets and geometrics, Table 5). For our analysis, we have also included the Olga Grande 6 (OGVI) lithic assemblage, including geometrics (triangular, trapezoid or segment of circle), that could be assigned typologically to the Late Mesolithic, dated c. $7000 / 7500$ BP in the nearby Prazo site (Monteiro-Rodrigues, 2011).

In order to perform a principal component analysis for the Côa Valley sites' blades and bladelets, we defined the assemblage of each type of bladelet from a given phase and a given site as an individual. This resulted in a universe of 44 individuals, which is far less than the desirable minimum number. This problem is amplified by the great number of our variables, the raw material used in the production of bladelets (22). The results are, however, too suggestive to be ignored. The analysis showed a strong contrast between a group composed of raw materials mainly from long distance sources (D1/2, H1, E2/7 and I1) but also some from regional (M1 and $\mathrm{J} 1$ ) and local sources (J15), and another formed essentially by local raw materials (J11, J12 and J13 quartz varieties) some regional (J2
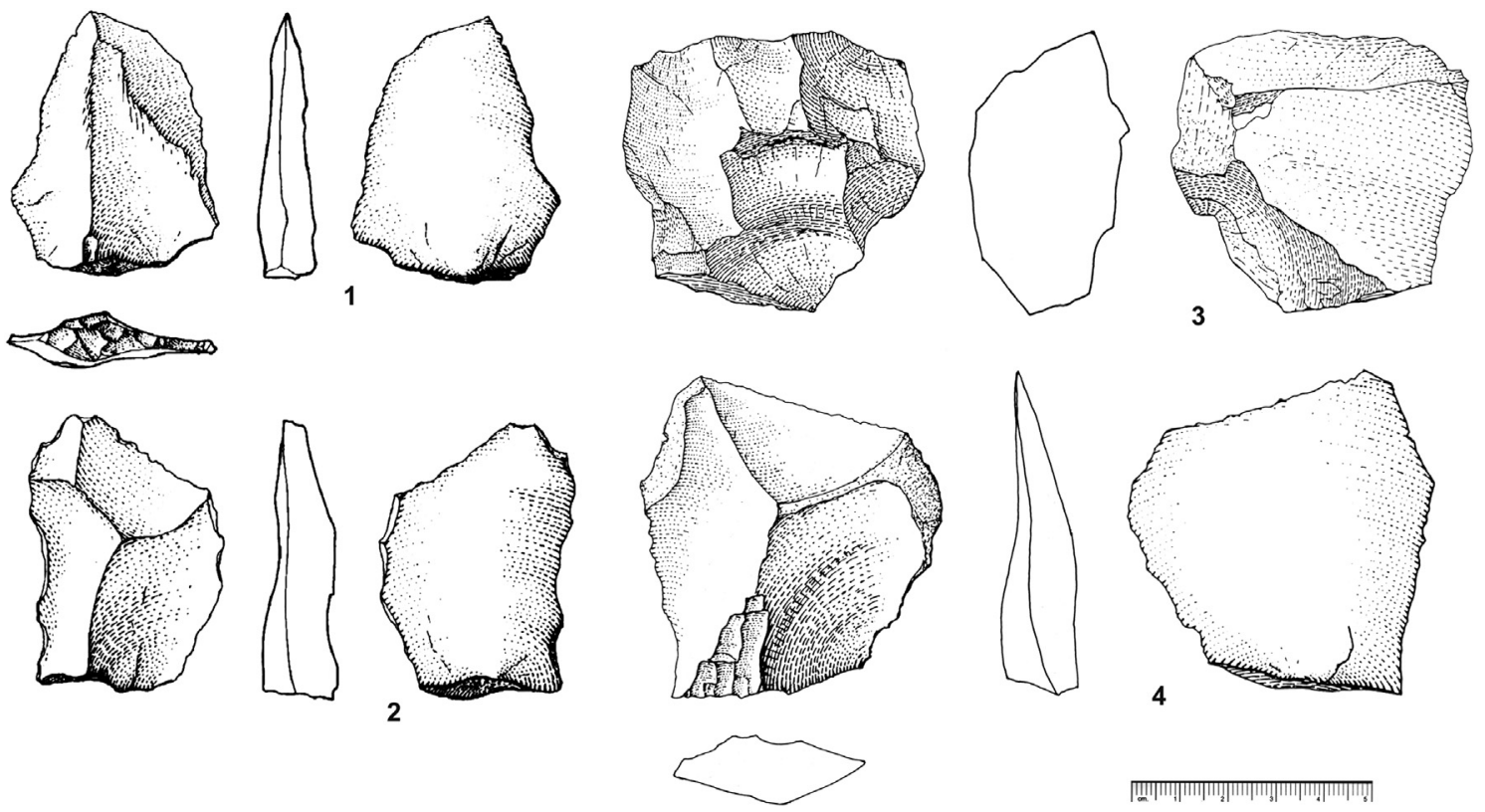

Fig. 6. Levallois material from Olga Grande 2, level 2 (1 and 2) Olga Grande 4, level 5 (3 and 4). 


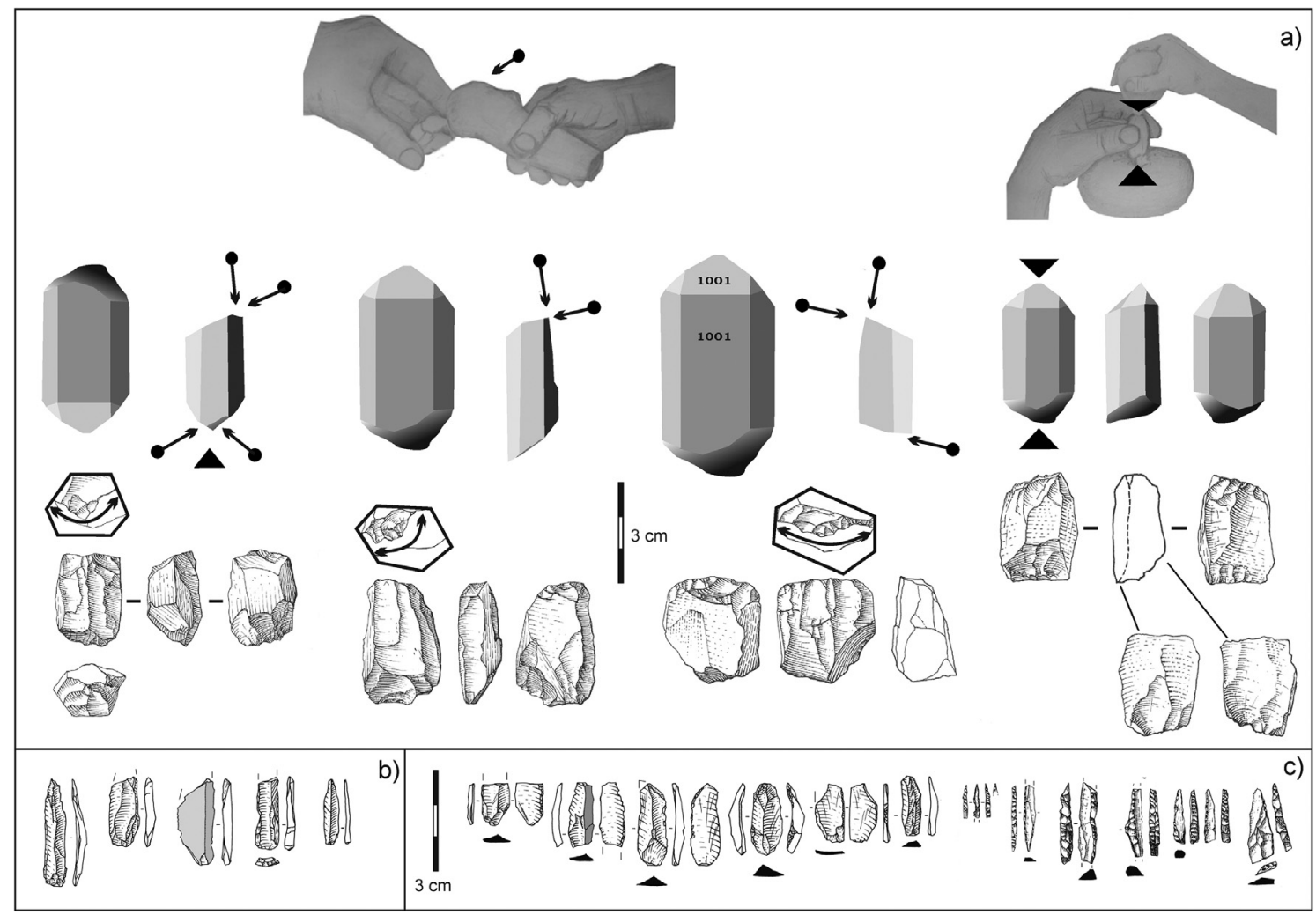

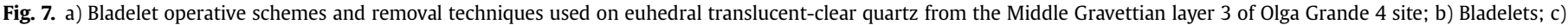
Retouched bladelets types (from Aubry (2009) and Klaric (2009) modified).

and $\mathrm{K} 1$ ) and residual long distance sources (I11, I7 and H2). A second less clear difference can be determined based on the presence or absence of J9, J10 and J14 local quartz varieties (Fig. 10). In the cases of absence, there is a subtle association with the presence of A1 flint.

Adding typology as a supplementary qualitative variable to the individual factor map, when we look to the barycentres of the four tool types (Fig. 11) no pattern is clearly distinguished. However, when we analyse the same map, adding phasing as a supplementary qualitative variable (Fig. 12), it is clear that the cultural phases' barycentres are distributed along the first contrast mentioned above, according to a chronological sequence, in which we see clearly the progressive increase of quartz (J11, J12 and J13 varieties) in the production of bladelets through time. There is a reduction of the variety of the raw material of distant sources, although new varieties emerge (I11, I7 and H2). Only the Mesolithic assemblage (geo-OGV[Meso]) is outside this trend, which could suggest a rupture with previous cultures. On the other hand, the line defined by the barycentres of the Upper Palaeolithic cultures suggests that the change of the raw material through time is progressive.
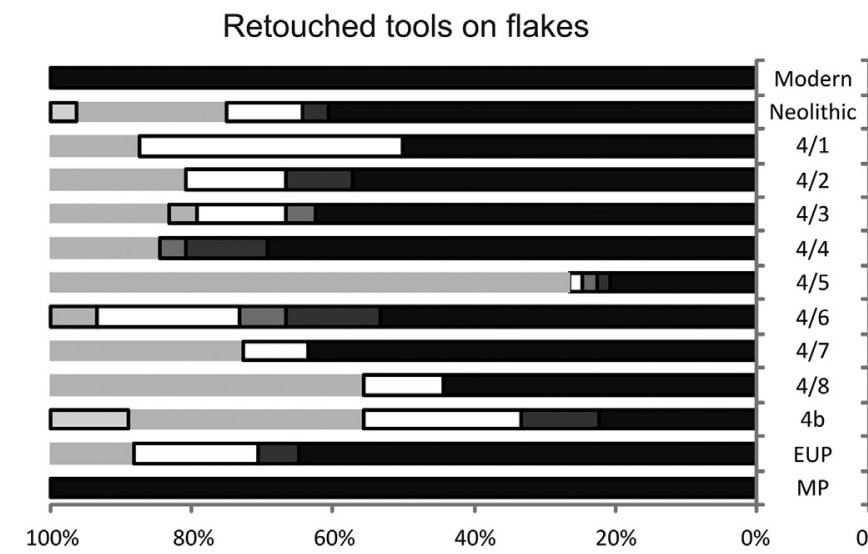

Retouched tools on blades and bladelets

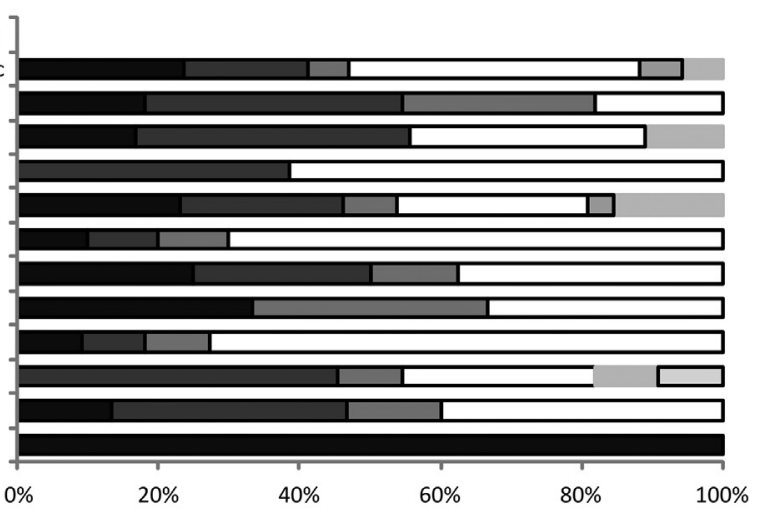

Anhedral quartz $\square$ Euhedral quartz $\square$ Micro-quartz vein

Flint/silcrete $\square$ Rhyolite Metasediment $\square$ Micro-gabbro

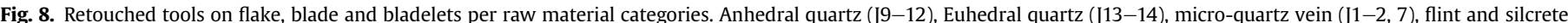

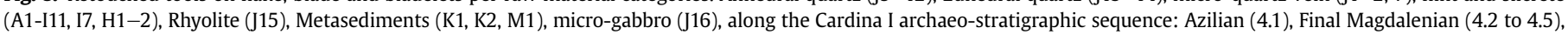
Magdalenian to Gravettian (4.6 to 4.8), Middle Gravettian (4b), Early Upper Palaeolithic (EUP), Middle Palaeolithic (MP). 
Table 4

Fariseu, layer 4 (Azilian) tool types per raw material category.

\begin{tabular}{|c|c|c|c|c|c|c|c|c|c|}
\hline \multirow[t]{2}{*}{ Type } & \multicolumn{3}{|l|}{ Flint } & \multicolumn{5}{|c|}{ Hydrothermal veins } & \multirow{2}{*}{$\frac{\text { Meta-sediment }}{\mathrm{K} 2}$} \\
\hline & $\mathrm{E} 2 / 7$ & $\mathrm{I} 1$ & Undet. & $\mathrm{J} 2$ & J9 & $\mathrm{J} 10 / 11$ & $\mathrm{~J} 12$ & $\mathrm{~J} 13 / 14$ & \\
\hline Double endscraper & - & - & - & - & - & - & - & - & 1 \\
\hline Endscraper on blade & - & - & - & - & 1 & - & - & - & - \\
\hline Endscraper on flake & - & - & - & - & - & 1 & - & - & - \\
\hline Atypical carinated endscraper & - & - & - & - & 1 & 2 & - & - & - \\
\hline Thick muzzled endscraper & - & - & - & - & 1 & - & - & - & - \\
\hline Flat muzzled endscraper & - & - & - & - & 1 & - & - & - & - \\
\hline Notched piece & - & - & - & - & 1 & 9 & 1 & 1 & 3 \\
\hline Denticulated piece & - & - & - & - & 1 & 3 & - & - & 1 \\
\hline Splintered piece & - & - & - & - & 8 & 3 & 2 & 9 & - \\
\hline Sidescraper & - & - & - & - & - & 1 & - & - & - \\
\hline "Vascas" sidescraper & - & - & - & - & - & 1 & - & - & - \\
\hline Segment of a circle & - & - & - & - & - & - & - & 1 & - \\
\hline Backed bladelet & - & 1 & - & - & - & - & - & 1 & - \\
\hline Denticulated backed bladelet & - & - & - & - & - & - & - & 2 & - \\
\hline "Areeiro" marginally retouched bladelet & - & 2 & 1 & - & - & - & - & 5 & - \\
\hline Marginally retouched bladelet & 1 & - & - & - & - & - & 1 & 1 & - \\
\hline Azilian point & - & 1 & - & 1 & - & - & 1 & 1 & - \\
\hline Ogival point & - & 1 & - & - & - & - & - & - & - \\
\hline Blade, flake and bladelet with discontinuous retouch & 1 & - & - & - & 5 & 22 & - & 2 & 5 \\
\hline Flake or blade fragment with continuous retouch & - & - & - & - & 1 & 7 & - & - & - \\
\hline Total & 2 & 5 & 1 & 1 & 20 & 49 & 5 & 23 & 10 \\
\hline
\end{tabular}

\section{Conclusion}

Raw material survey has confirmed that most of the different quartz varieties used in the Côa Valley are available in vein outcrops or slope deposits at the proximity of the sites studied (Fig. 3). The continuation of surveys has also revealed the systematic use of regional geographically restricted categories of fine-grained quartz and chalcedony veins, revealing a deep knowledge of the territory resources, attested by systematic displacements of these varieties, from 20 to $40 \mathrm{~km}$ (Fig. 2). A more precise reconstruction of the modalities of exploitation of these sources (gathering quartz vein fragments or core preparation near primary outcrops) could be

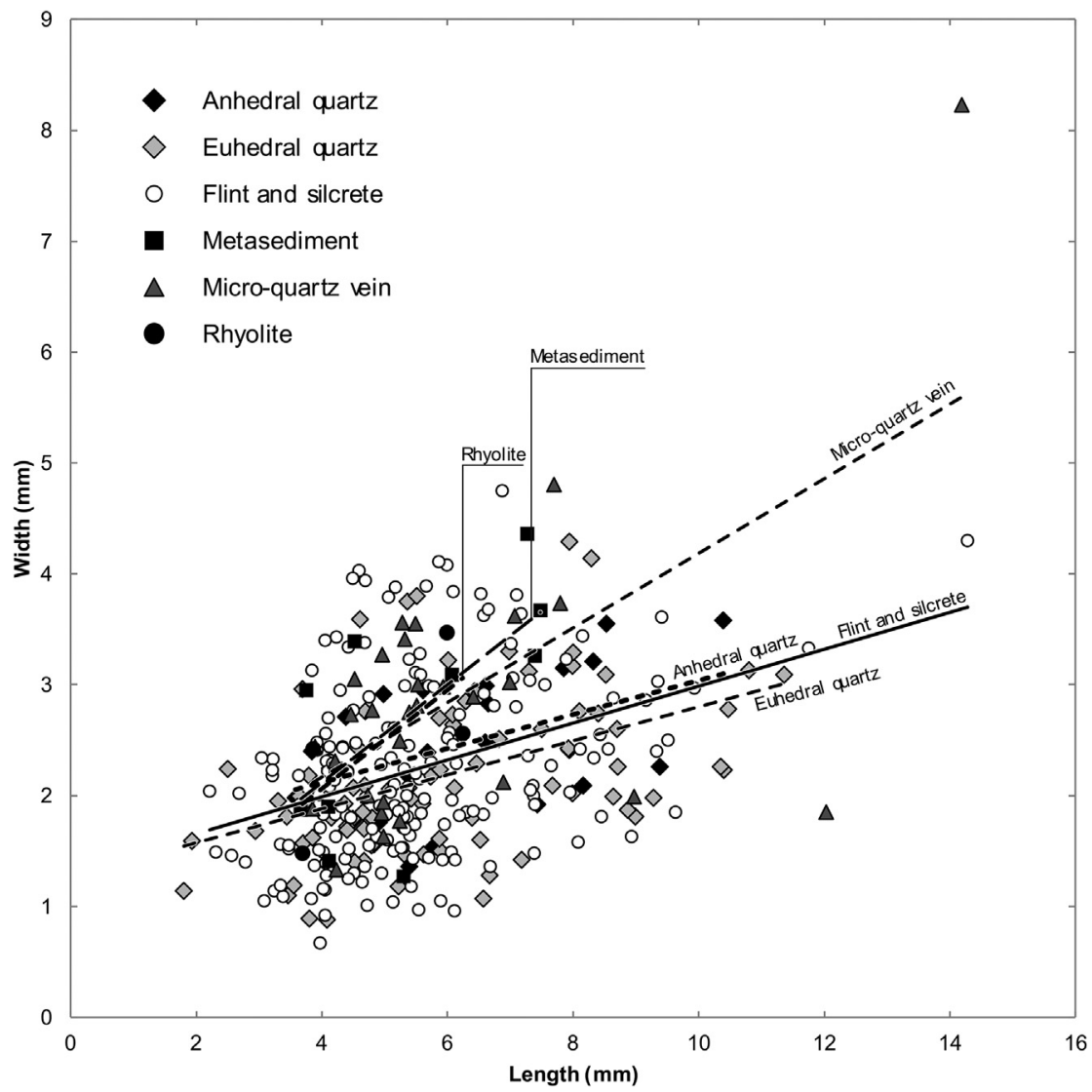

Fig. 9. Length/width ratio for retouched bladelet tools from the Upper Palaeolithic Côa valley occupation. 
Table 5

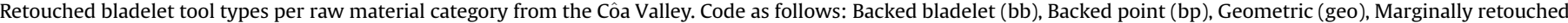

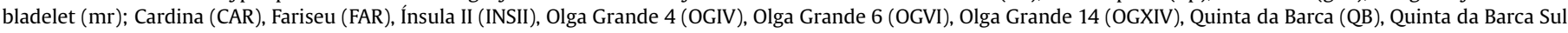
(QBS); Middle Gravettian (MG), Late Gravettian (LG), Magdalenian (Mag), Azilian (Az), Mesolithic (Meso) and Undetermined Upper Palaeolithic (SM).

\begin{tabular}{|c|c|c|c|c|c|c|c|c|c|c|c|c|c|c|c|c|c|c|c|c|c|c|}
\hline \multirow[b]{2}{*}{ Code } & \multicolumn{4}{|c|}{ Anhedral quartz } & \multicolumn{2}{|c|}{ Euhedral quartz } & \multicolumn{10}{|c|}{ Flint and silcrete } & \multicolumn{3}{|c|}{ Microquartz } & \multicolumn{2}{|c|}{ Metasediment } & \multirow{2}{*}{$\frac{\text { Rhyolite }}{\mathrm{J} 15}$} \\
\hline & $\mathrm{J} 10$ & $\mathrm{~J} 11$ & $\mathrm{~J} 12$ & J9 & $\mathrm{J} 13$ & $\mathrm{~J} 14$ & A1 & $\mathrm{C} 3 / 4$ & $\mathrm{D} 1 / 2$ & $\mathrm{E} 2 / 7$ & $\mathrm{H} 1$ & $\mathrm{H} 2$ & I1 & I11 & $\mathrm{I} 2 / 3$ & I7 & $\mathrm{J} 1$ & $\mathrm{~J} 2$ & $\mathrm{~J} 5$ & $\mathrm{~K} 1$ & M1 & \\
\hline bb-CAR(Az) & - & - & - & 2 & 3 & - & - & - & - & - & - & 1 & 3 & - & - & - & - & 1 & 2 & - & 1 & - \\
\hline bb-CAR(LG) & - & - & - & - & 3 & - & - & - & - & 3 & 1 & 2 & 6 & 1 & - & 2 & 1 & - & - & - & 1 & 1 \\
\hline bb-CAR(Mag) & 3 & 1 & - & 1 & 6 & - & - & 1 & 2 & 6 & - & - & 7 & - & 1 & - & 1 & 1 & - & - & - & - \\
\hline bb-CAR(MG) & - & - & - & - & 4 & - & - & 2 & 1 & 7 & 5 & - & - & - & 1 & - & 4 & - & - & - & 5 & 1 \\
\hline bb-CAR(SM) & - & 1 & - & - & 4 & - & - & 4 & 2 & 2 & - & - & 2 & - & - & - & 3 & - & - & - & - & - \\
\hline bb-FAR(Az) & - & - & - & - & - & - & - & - & - & - & - & - & - & 1 & - & - & - & - & - & - & - & - \\
\hline bb-INSII(LG) & - & - & - & - & - & - & - & - & - & 1 & - & - & 2 & - & - & - & 1 & - & - & - & - & - \\
\hline bb-OGIV(Mag) & - & - & - & - & 1 & - & - & - & - & 1 & - & - & 2 & 2 & - & - & - & - & - & - & - & - \\
\hline bb-OGIV(MG) & - & - & - & - & 5 & - & - & - & 1 & - & 1 & - & 2 & - & 1 & - & - & - & - & 1 & - & - \\
\hline bb-OGXIV(MG) & - & - & - & - & 1 & - & - & - & - & - & - & - & 2 & - & - & - & 1 & - & - & - & - & - \\
\hline bb-QB(Mag) & - & 1 & 1 & - & - & - & - & - & - & - & - & - & - & - & - & - & - & 1 & - & - & - & - \\
\hline bb-QBS(Az) & - & - & - & - & 1 & - & - & - & - & - & - & - & - & - & - & - & - & 1 & - & - & - & - \\
\hline bp-CAR(Az) & - & - & - & - & - & - & - & 1 & - & - & - & - & 1 & - & - & - & - & - & - & - & - & - \\
\hline bp-CAR(LG) & - & - & - & - & - & - & - & 1 & - & - & - & - & - & - & - & - & - & - & - & - & - & - \\
\hline bp-CAR(Mag) & - & - & - & - & - & - & - & - & - & - & - & - & - & - & - & - & - & 1 & - & - & - & - \\
\hline bp-CAR(MG) & - & - & - & - & - & - & - & - & - & 1 & - & - & 4 & - & 1 & - & 3 & - & - & - & - & - \\
\hline bp-CAR(SM) & - & - & - & - & - & - & - & - & - & - & - & 1 & - & - & - & - & - & - & - & - & - & - \\
\hline bp-FAR(Az) & - & 1 & 1 & 1 & - & - & - & - & - & - & - & - & - & 1 & - & - & - & 1 & - & - & - & - \\
\hline bp-OGIV(Mag) & - & - & - & - & - & - & - & - & - & - & - & - & 2 & - & - & - & - & - & - & - & - & - \\
\hline bp-OGIV(MG) & - & - & - & - & 3 & - & - & - & - & - & - & - & 3 & - & - & - & 1 & - & - & - & - & - \\
\hline bp-OGXIV(MG) & - & - & - & - & - & - & - & - & - & - & - & - & 1 & - & - & - & - & - & - & - & - & - \\
\hline bp-QB(Mag) & - & 1 & - & - & - & - & - & - & - & - & - & - & - & - & - & - & - & - & - & - & - & - \\
\hline bp-QBS(Az) & - & - & - & - & - & - & - & - & - & - & - & - & 1 & - & - & - & - & 2 & - & - & 1 & - \\
\hline geo-CAR(Az) & - & - & - & 2 & 1 & - & - & - & - & - & - & - & - & - & - & - & - & - & - & - & - & - \\
\hline geo-CAR(Mag) & - & 1 & - & - & 6 & - & - & - & - & - & - & - & - & - & - & - & - & - & - & - & - & - \\
\hline geo-CAR(SM) & - & - & - & - & 2 & - & - & - & - & - & - & - & - & - & - & - & - & - & - & - & - & - \\
\hline geo-FAR(Az) & - & - & - & - & 1 & - & - & - & - & - & - & - & - & - & - & - & - & - & - & - & - & - \\
\hline geo-OGIV(Mag) & - & - & - & - & 1 & - & - & - & - & - & - & - & - & - & - & - & - & - & - & - & - & - \\
\hline geo-OGIV(MG) & - & - & - & - & 3 & - & - & - & - & - & - & - & 1 & - & 1 & - & - & - & - & - & - & - \\
\hline geo-OGVI(Meso) & - & - & 1 & - & 5 & 1 & - & - & - & - & - & - & - & - & - & - & - & - & - & - & - & - \\
\hline geo-QB(Mag) & - & 2 & - & - & - & - & - & - & - & - & - & - & - & - & - & - & - & - & - & - & - & - \\
\hline geo-QBS(Az) & - & - & - & - & 3 & - & - & - & - & - & - & - & - & - & - & - & - & - & - & - & - & - \\
\hline mr-CAR(Az) & - & - & - & - & 1 & - & - & 1 & - & - & - & - & 1 & - & - & - & - & - & - & - & - & - \\
\hline mr-CAR(LG) & - & - & - & - & 4 & - & - & - & - & 2 & - & - & 1 & - & - & 1 & - & - & - & - & - & - \\
\hline mr-CAR(Mag) & - & 1 & - & - & 4 & - & - & 3 & 1 & 8 & - & - & 4 & - & 1 & - & - & - & - & - & - & 1 \\
\hline mr-CAR(MG) & - & - & - & - & 9 & - & 1 & - & - & - & - & - & 2 & - & 2 & 1 & - & - & - & - & - & - \\
\hline mr-CAR(SM) & - & - & - & - & 5 & - & - & - & - & 2 & - & - & 1 & - & - & - & - & - & - & - & - & - \\
\hline mr-FAR(Az) & - & - & 1 & - & 8 & - & - & - & - & - & - & - & - & 3 & - & - & - & - & - & - & - & - \\
\hline mr-INSII(LG) & - & - & - & - & - & - & - & - & - & - & - & - & - & - & - & - & - & - & - & 1 & - & - \\
\hline mr-OGIV(Mag) & - & - & - & - & - & - & - & - & - & 1 & - & - & 1 & - & - & - & - & - & - & - & - & - \\
\hline mr-OGIV(MG) & - & - & - & - & 3 & - & - & - & - & 1 & - & - & 2 & - & - & - & - & - & - & - & - & - \\
\hline mr-OGXIV(MG) & - & - & - & - & 1 & - & - & - & - & - & - & - & - & - & - & - & - & - & - & - & - & - \\
\hline mr-QB(Mag) & - & - & - & - & - & - & - & - & - & - & - & - & - & - & - & 1 & - & 1 & - & - & - & - \\
\hline $\mathrm{mr}-\mathrm{QBS}(\mathrm{Az})$ & - & - & - & - & 1 & - & - & - & - & - & - & - & - & - & - & - & - & - & - & - & - & - \\
\hline
\end{tabular}

obtained by extending systematic surveys. The distinction between brown/yellow microquartz (J1) of the right margin of the Douro Valley and Côa Valley sources, to the north and the south of the sites, respectively (Fig. 2), and its implication for the social network reconstruction should be determined by geochemical analysis. Although the excavated area is still limited and no chronometric data is available yet, the Middle Palaeolithic lithic assemblages recovered at the Cardina I site and Olga Grande 4 and 2 show the dominant use of raw materials present in the settlement vicinities (anhedral quartz and rhyolite for Cardina, rhyolite and quartzite for Olga Grande 2 and 4 ) the absence of most of the regional and all of the long distance sources systematically used during all the Upper Palaeolithic.

The Upper Palaeolithic assemblages show a wider source network, including all the local and regional siliceous rocks and extra-regional flint and silcrete. The exploitation of the local quartz varieties in association with other local, regional and extra-regional sources shows a trend though time. During all the phases of the Upper Palaeolithic, retouched flake tools are mainly done on the local quartzite and anhedral varieties of quartz. Frequency of nonretouched blanks of these materials and use-wear analysis suggest immediate use and discard of the raw and retouched quartz and quartzite flakes produced on the Côa valley sites. Retouched bladelet tools are produced on a large variety of raw materials, preferentially extra-regional flint and silcrete, but also euhedral local quartz and anhedral translucent quartz and rhyolite and regional hornfels and iron siltstone. Independently of the chronology, statistical analysis of Upper Palaeolithic retouched bladelets does not reveal a clear relation between typology and the raw material. Nevertheless, statistical analysis indicates slight differences in preferences from the Middle Gravettian to the Azilian, when considering bladelet tool raw materials. If the same large 
Variables factor map (PCA)

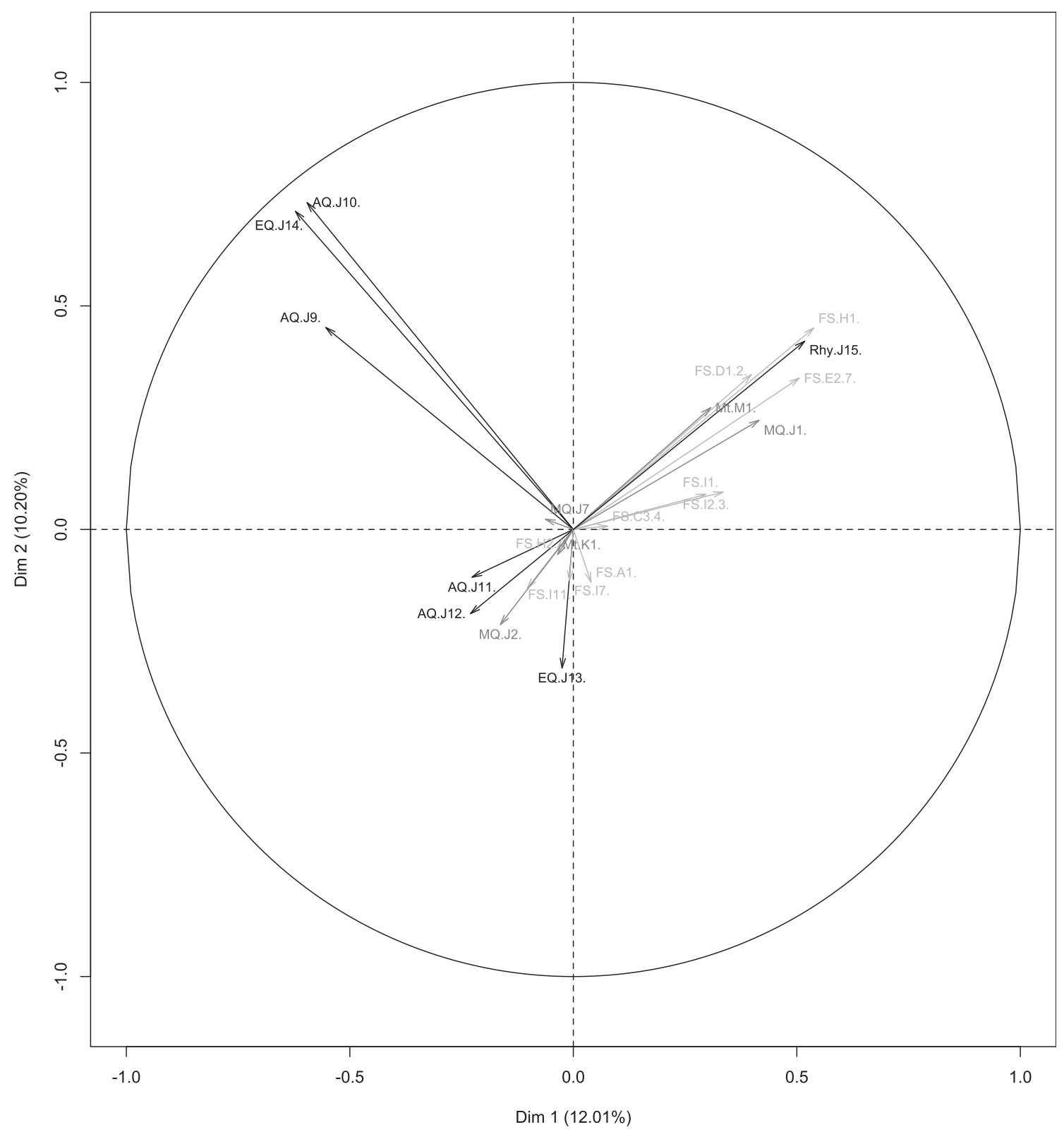

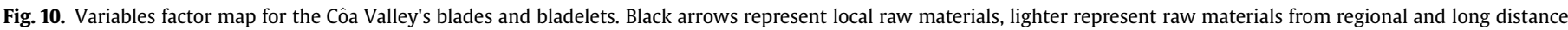
sources. (See Table 1 for raw material type).

geographic range and diversity of lithic raw material supply is generally the same throughout the Upper Palaeolithic, over time there is a constriction in the raw material supply range (Aubry et al., 2012). This general trend seems to be confirmed by the known Mesolithic assemblage, essentially focused on local euhedral and anhedral quartz varieties for the production of the bladelets retouched into geometrics tools, even if exotic flint is not completely absent.

In the Côa Valley, quartz and quartzite are dominant in all knapped industries. Our study highlights the importance of the knowledge of local and regional raw material varieties in the study of lithic economy, namely in an area where flint and silcrete are absent, opening new prospects for the survey of similar areas.
A fine-grained study of the raw materials economy shows differences through time. Keeping in mind the constraints related to the Middle Palaeolithic technology, first results from the Côa Valley, where flint is regionally absent, hint different behaviours between Neanderthal and Modern Human societies, concerning territory exploitation and/or raw material choices, and have implications on territoriality and social networks, which future works will enlighten. Further excavation and dating of Middle Palaeolithic occupations at Cardina and other sites will be required, as well as a thinner analysis of both the possible relation between Upper Palaeolithic raw material procurement strategies and cold millennial-scale climate oscillations, and the transition to Holocenic societies. 


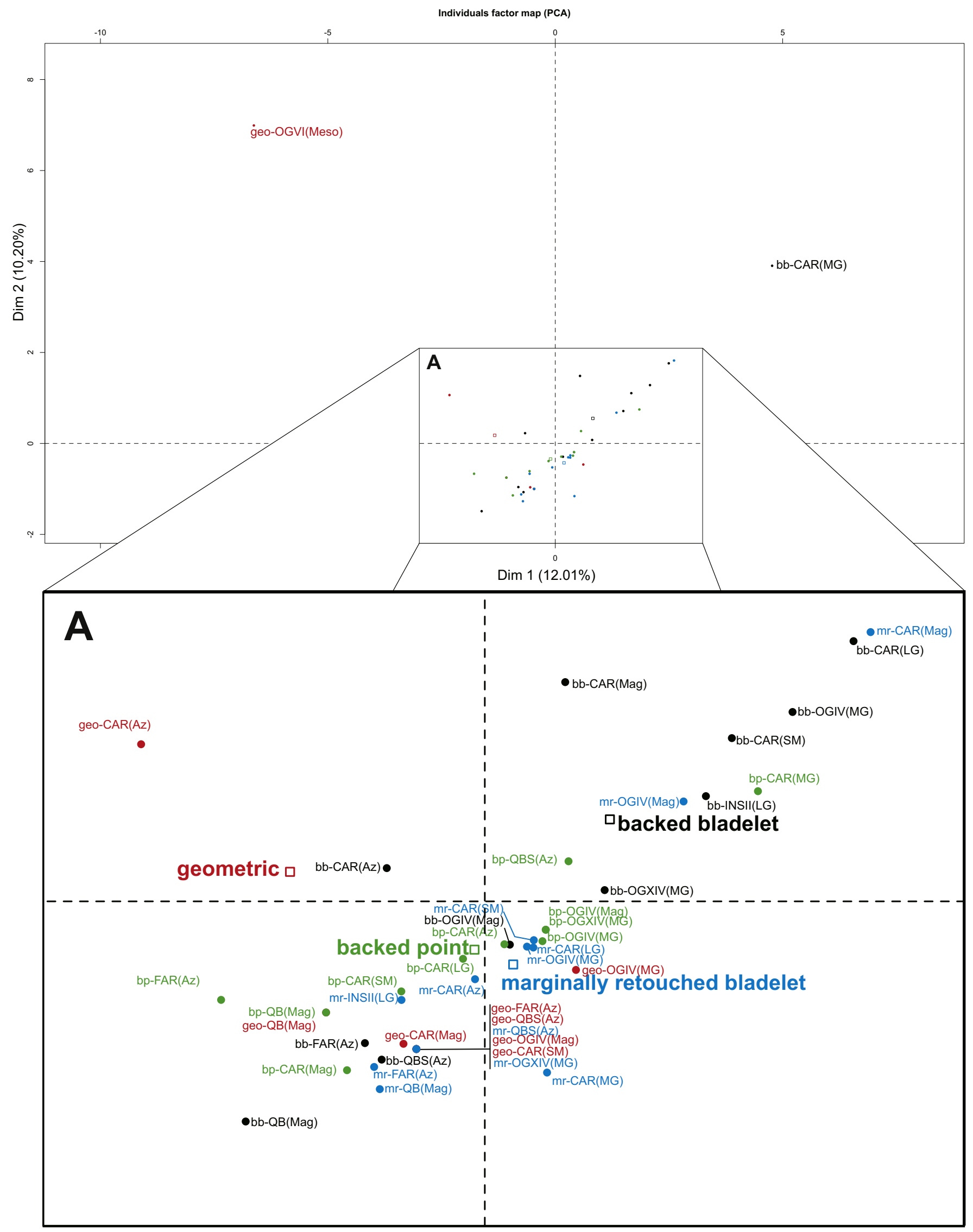

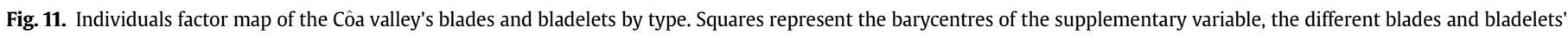
types. (See Table 5 for abbreviations). 


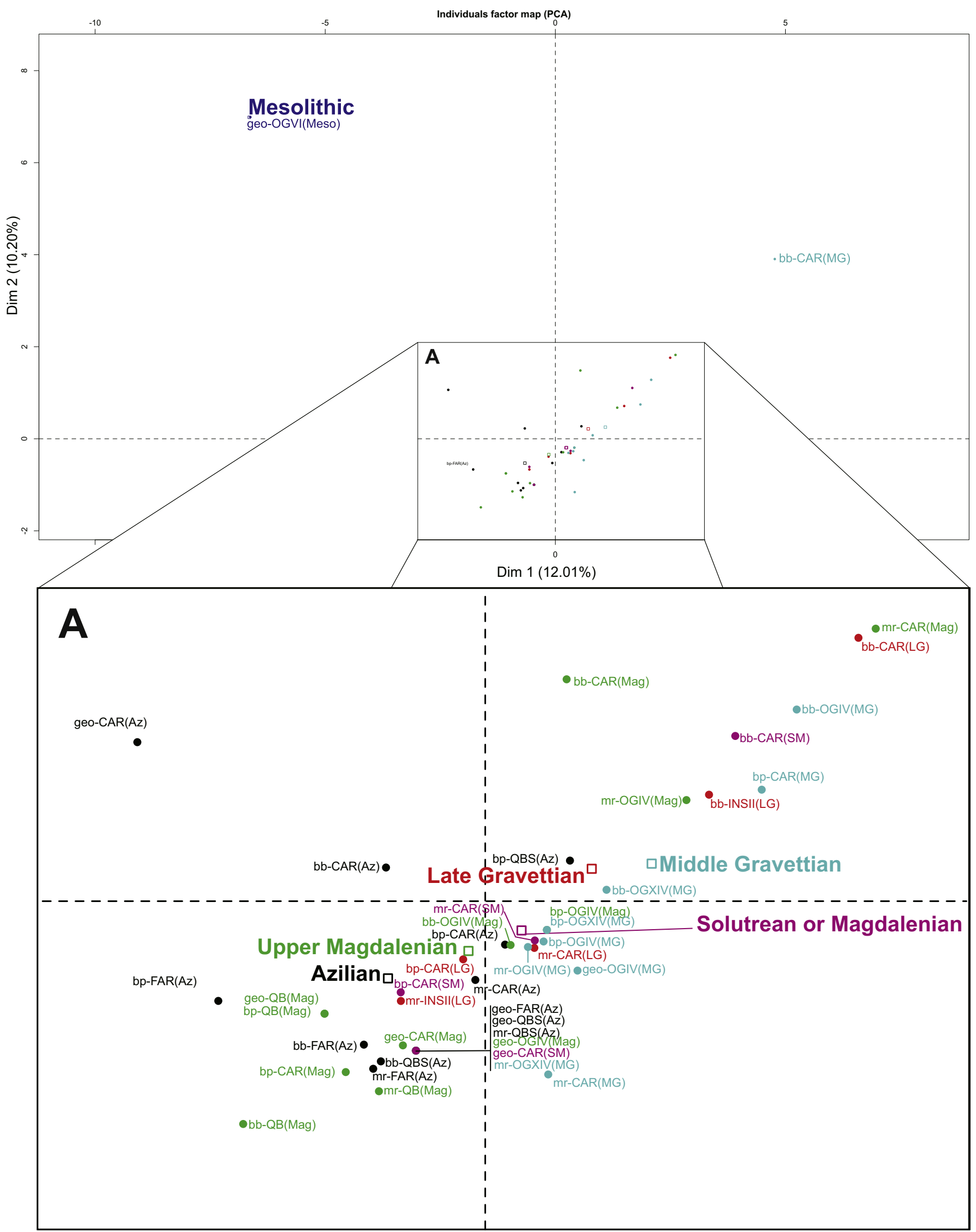

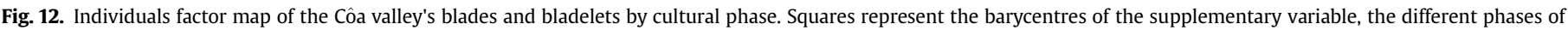
blades and bladelets. (See Table 5 for abbreviations). 


\section{Acknowledgements}

This study is a contribution to the Project PALÆCOA: Neanderthal to Anatomically Modern Human transition in the Côa Valley: Environments, Symbolism and Social networks (PTDC/ EPH-ARQ/0326/2014), funded by Fundação Ciência e Tecnologia (FCT) and the Europe 2020 Programme. The DGPC provided permit for this project. We thank the Fundação Côa Parque for its logistical support and permission to conduct the project on which this study is based. We also acknowledge the contribution from the Vila Nova de Foz Côa and Santa Comba Municipalities for providing logistical help for the excavation works at Cardina site, and Ana Cristina Araújo, José Paulo Ruas, Cristina Gameiro and Henrique Matias for their contribution to the excavation work and raw material survey.

\section{References}

Almeida, F., 2000. The Terminal Gravettien of Portuguese Estremadura. Southern Methodist University (PhD Dissertation).

Aubry, T., 2001. L'occupation de la basse vallée du Côa pendant le Paléolithique supérieur. In: Zilhão, J., Aubry, T., Carvalho, A.F. (Eds.), Les premiers hommes modernes de la péninsule ibérique (Actes du Colloque de la Commission VIII de l'UISPP. Vila Nova de Foz Côa, 22-24 Octobre 1998). Instituto Português de Arqueologia (Trabalhos de Arqueologia 17), Lisboa, pp. 253-273.

Aubry, T., 2002. Le contexte archéologique de l'art paléolithique à l'air libre de la vallée du Côa. In: Sacchi, D. (Ed.), L'Art Paléolithique à l'Air Libre: Le paysage Modifié par l'Image (Tautavel, Campôme, 7-9 octobre 1999). GAEP; GÉOPRE, Saint-Estève, pp. 25-38.

Aubry, T. (Ed.), 2009. 200 séculos de história do Vale do Côa: Incursões na vida quotidiana dos cacadores-artistas do Paleolítico. IGESPAR, I.P. (Trabalhos de Arqueologia 52), Lisboa.

Aubry, T., Araújo Igreja, M., 2009. Economy of lithic raw material during the Upper Paleolithic of the Côa Valley and the Sicó Massif (Portugal): technological and functional perspectives. In: Araújo Igreja, M., Clemente Conte, I. (Eds.), Proceedings of the Workshop Functional Studies of Non Flint Stone Tools: Methodological Improvements and Archaeological Inferences. Lisboa, 23-25 may 2008 [online]. Available. http://www.arte-coa.pt/Ficheiros/Bibliografia/1203/ 1203.pt.pdf (Jan. 10, 2012).

Aubry, T., Sampaio, J.D., 2008. Fariseu: new chronological evidence for open-air Palaeolithic art in the Côa valley (Portugal). Antiquity 82 (316) [online series] Available. http://antiquity.ac.uk/ProjGall/aubry316/ (Oct. 13, 2015).

Aubry, T., Mangado Llach, X., Sellami, F., Sampaio, J.D., 2002. Open-air rock-art, territories and modes of exploitation during the Upper Paleolithic in the Côa Valley (Portugal). Antiquity 76 (291), 62-76.

Aubry, T., Luís, L., Sampaio, J.D., 2007. Primeira datação absoluta para a arte paleolítica ao ar livre: os dados do Fariseu (Vila Nova de Foz Côa). Al-Madan 14, 48-52.

Aubry, T., Dimuccio, L.A., Bergadà, M.M., Sampaio, J.D., Sellami, F., 2010. Palaeolithic engravings and sedimentary environments in the Côa River Valley (Portugal): Implications for the detection, interpretation and dating of open-air rock art. Journal of Archaeological Science 37 (12), 3306-3319.

Aubry, T., Luís, L., Dimuccio, L.A., 2012. Nature vs. Culture: present-day spatial distribution and preservation of open-air rock art in the Côa and Douro River Valleys (Portugal). Journal of Archaeological Science 39 (4), 848-866.

Aubry, T. Mangado Llach, X. Matias, H., 2014a. Matérias-primas das ferramentas em pedra lascada da Pré-história do Centro e Nordeste de Portugal. In: Dinis, P.A., Gomes, A., Monteiro-Rodrigues, S. (Eds.), Proveniência de materiais geológicos: abordagens sobre o Quaternário. Associação Portuguesa para o Estudo do Quaternário, pp. 165-192.

Aubry, T., Santos, T.A., Luís, L., 2014b. Stratigraphies du panneau 1 de Fariseu: analyse structurelle d'un système graphique paléolithique à l'air libre de la vallée du Côa (Portugal). In: Paillet, P. (Ed.). Les arts de la Préhistoire: microanalyses, mises en contextes et conservation: Actes du colloque «Micro-analyses et datations de l'art préhistorique dans son contexte archéologique», MADAPCA, Paris, 16-18 novembre 2011. Société des Amis du Musée National de Préhistoire et de la Recherche Archéologique (Paléo, numéro spécial), Les Eyzies-de-Tayac, pp. 259-270.

Baptista, A.M., 1999. No tempo sem tempo: A arte dos caçadores paleolíticos do Vale do Côa. Parque Arqueológico do Vale do Côa, Vila Nova de Foz Côa.

Baptista, A.M., 2009. O paradigma perdido: O Vale do Côa e a arte paleolítica de ar livre em Portugal. Edições Afrontamento, Porto.

Bicho, N.F., 2000. Paleolithic occupation and environment of central and southern Portugal during Isotopic Stages 2 and 3. In: Vermeersch, P., RenaultMiskovsky, J. (Eds.), European Late Pleistocene Isotopic Stages 2 \& 3: Humans, Their Ecology and Cultural Adaptations. Université de Liège, Liège, pp. 43-56.

Cabral, J., 1989. An example of intraplate neotectonic activity, Vilariça basin, Northeast Portugal. Tectonics 8, 285-303.

Carvalho, D., 1992. Carta Geológica de Portugal, Escala 1: 500 000. Serviço Geológico de Portugal \& Instituto Geográfico e Cadastral, Lisboa.
Cerveira, A., 1951. Sobre a metalogenia do urânio em Portugal. Boletim da Sociedade Geológica de Portugal 8 (3), 141-182.

R Core Team, 2013. R: a Language and Environment for Statistical Computing. R Foundation for Statistical Computing, Vienna, Austria [online]. Available. http:// www.R-project.org/ (Oct. 29, 2016).

Davidson, I., 1986. The geographical study of Late Palaeolithic stages in Eastern Spain. In: Bailey, G., Callow, P. (Eds.), Stone Age Prehistory: Studies in Memory of Charles MacBurney. Cambridge University Press, Cambridge, pp. 95-118.

Fernandes, P., Raynal, J.P., Moncel, M.H., 2008. Middle Palaeolithic raw material gathering, territories and human mobility in the southern Massif Central, France: first results from a petro-archaeological study on flint. Journal of Archaeological Science 35, 2367-2370.

Gabriel, S., Béarez, P., 2009. Caçadores-pescadores do vale do Côa: os restos de fauna do sítio do Fariseu. In: Aubry, T. (Ed.), 200 séculos de história do Vale do Côa: Incursões na vida quotidiana dos caçadores-artistas do Paleolítico. IGESPAR, I.P. (Trabalhos de Arqueologia 52), Lisboa, pp. 331-339.

Gameiro, C., 2009. Utensílios e suportes microlíticos do Magdalenense final no Vale do Côa: o exemplo da U.E. 4 do Fariseu. In: Aubry, T. (Ed.), 200 séculos de história do Vale do Côa: Incursões na vida quotidiana dos caçadores-artistas do Paleolítico. IGESPAR, I.P. (Trabalhos de Arqueologia 52), Lisboa, pp. 256-268.

Husson, F., Josse, J., Le, S., Mazet, J., 2013. FactoMineR: Multivariate Exploratory Data Analysis and Data Mining with R. R Package Version 1.24 [online]. Available. http://CRAN.R-project.org/package=FactoMineR (Oct. 29, 2016).

Klaric, L., 2009. Les systèmes de production de supports d'armatures et leur place dans la gestion de ressources lithiques: une voie privilégiée pour la compréhension des sociétés gravettiennes de la Vallée du Côa. In: Aubry, T. (Ed.), 200 séculos de história do Vale do Côa: Incursões na vida quotidiana dos caçadores-artistas do Paleolítico. IGESPAR, I.P. (Trabalhos de Arqueologia 52), Lisboa, pp. 247-256.

Klaric, L., Guillermin, P., Aubry, T., 2009. Des armatures variées et des modes de productions variables: Réflexions à partir de quelques exemples issus du Gravettien d'Europe occidentale (France, Portugal, Allemagne). Gallia Préhistoire 51, 113-154.

Mangado Llach, X., 2005. La caracterización y el aprovisionamiento de los recursos líticos en la prehistoria de Cataluña: las materias primas silíceas del Paleolítico Superior Final y el Epipaleolítico. British Archaeological Reports (S1420), Oxford.

Mercier, N., Valladas, H., Froget, L., Jorons, J.L., Aubry, T., 2001. Application de la méthode de la thermoluminescence à la datation des occupations paléolithiques de la vallée du côa. In: Zilhão, J., Aubry, T., Carvalho, A.F. (Eds.), Les premiers hommes modernes de la péninsule ibérique (Actes du Colloque de la Commission VIII de l'UISPP, Vila Nova de Foz Côa, 22-24 octobre 1998). Instituto Português de Arqueologia (Trabalhos de Arqueologia 17), Lisboa, pp. 275-280.

Mercier, N., Valladas, H., Aubry, T., Zilhão, J., Jorons, J.L., Reyss, J.L., Sellami, F., 2006. Fariseu: first confirmed open-air Palaeolithic parietal art site in the Côa Valley (Portugal). Antiquity 80 (310). Project Gallery. [online series]. Available. http:/ antiquity.ac.uk/projgall/mercier/ (Oct. 13, 2015).

Monteiro-Rodrigues, S., 2011. Pensar o Neolítico Antigo: contributo para o estudo do Norte de Portugal entre o VII e o V Milénios a.C. Centro de Estudos Préhistóricos da Beira Alta (Estudos Pré-Históricos 16), Viseu.

Pereira, E., 2001. Carta Geológica de Portugal, escala 1: 200000 e Noticia Explicativa da Folha 2. Instituto Nacional de Engenharia, Tecnologia e Inovação, Lisboa.

Pereira, D.M.I., 2006. Sedimentologia e estratigrafia do Cenozóico de Trás-osMontes oriental (NE Portugal). Minho University, Braga, Portugal (Ph.D. thesis).

Ribeiro, A., 1974. Contribution à l'étude tectonique de Trás-os-Montes oriental. Serviços Geológicos de Portugal (Memórias, Nova Série 24), Lisboa.

Ribeiro, A., 1981. A geotraverse through the Variscan fold belt in Portugal. In: Zwart, H.J., Dornsiepen, U.F. (Eds.), The Variscan Orogen in Europe. Geologie en Mijnbouw, vol. 60, pp. 41-44.

Ribeiro, M.L., 2001. Carta geológica simplificada do Parque Arqueológico do Vale do Côa, escala 1: 80 000. Instituto Geológico e Mineiro, Lisboa.

Ribeiro, A., Antunes, M.T., Ferreira, M.P., Rocha, M.P., Soares, A.F., Zbyszewski, G., Moitinho de Almeida, F., Carvalho, D., Monteiro, J.H., 1979. Introduction à la géologie générale du Portugal. Serviço Geológico de Portugal, Lisboa.

Ribeiro, A., Pereira, E., Dias, R., 1990. Allochthonous sequences: structure in the Northwest of the Iberian Peninsula. In: Dallmeyer, R.D., Martinez Garcia, E. (Eds.), Pre-Mesozoic Geology of Iberia. Springer-Verlag, Berlin, pp. 220-236.

Silva, A.F. Ribeiro, M.L., 1991. Carta Geológica de Portugal em escala 1: 50000 e Notícia explicativa da Folha 15-A: Vila Nova de Foz Côa. Serviço Geológico de Portugal, Lisboa.

Silva, A.F., Rebelo, J.A., Ribeiro, M.L., 1989. Carta Geológica de Portugal em escala 1: 50000 e Notícia explicativa da Folha 11-C: Torre de Moncorvo. Serviço Geológico de Portugal, Lisboa.

Valladas, H., Mercier, N., Froget, L., Jorons, J.L., Reyss, J.L., Aubry, T., 2001. TL dating of Upper Palaeolithic sites in the Côa Valley (Portugal). Quaternary Science Reviews 20, 939-943.

Zilhão, J., 1997a. O Paleolítico Superior da Estremadura Portuguesa. Edições Colibri, Lisboa.

Zilhão, J., 1997b. Arte rupestre e Pré-história do Vale do Côa. Trabalhos de 19951996. Ministério da Cultura, Lisboa.

Zilhão, J., Almeida, F., Aubry, T., Carvalho, A.F., Zambujo, G., 1995. O sítio arqueológico paleolítico do Salto do Boi (Cardina 1, Santa Comba, Vila Nova de Foz Côa). Trabalhos de Antropologia e Etnologia 35, 471-497. 